\title{
NARRATIVES OF LIFE AND VIOLENCE ALONG THE CHAD- CAMEROON OIL PIPELINE
}

Amber Murrey Geography and the Environment
University of Oxford, UK

Abstract

This article further develops a critical geographical theory of structural violence. It does so by considering the ways people in Nanga-Eboko and Kribi, two communities in Cameroon, report feeling and experiencing structural violence along the Chad-Cameroon Oil Pipeline. For people living within spaces (re)produced through structurally violent processes, projects, and extractions, a triad of intersecting experiences emerge: structural violence is felt as (i) tangible through the body (senses of loss, the belly, the body, and nourishment), or described through gendered narratives of hunger, illness, and the experiences of land dispossession; (ii) historically compounded, or characterized by a rootedness in the colonial and racist structures of the past alongside expectations that present-day structural violence threatens future generations; and (iii) spatially compounded, or experienced through a concurrent spatial overlapping (or compounding) as multiple forms of structural violence converge within the same landscapes and lifescapes, effecting displacement in-place. Each of these, felt simultaneously, has the effect of rendering structural violence acutely visible, tangible as it is in the restructurings of landscapes and lifescapes, despite discursive attempts to cloak, bury, and efface by powerful actors. Looking toward the narratives that people use to critique and engage with such violence provides conceptual tools for wider resistance practices against structural violence.
Keywords: displacement in-place; hunger; oil pipeline; politics of visibility; structural violence

\section{Narrativas de Violencia y Vida a lo largo del Oleoducto Chad-Camerún}

\section{Resumen}

Este artículo contribuye al desarrollo de una teoría geográfica crítica de la violencia estructural, considerando las formas en que los pueblos en Nanga-Eboko y Kribi (dos comunidades camerunesas) dicen sentir y experimentar la violencia estructural a lo largo del oleoducto Chad-Camerún. Para los pueblos que viven dentro de espacios (re)producidos mediante procesos, proyectos y extracciones estructuralmente violentos surge una tríada de experiencias interrelacionadas; la violencia estructural se siente: a) tangible en el cuerpo (el estómago, el cuerpo y las náuseas), o descrita a través de narrativas de género sobre hambre, enfermedad y experiencias de saqueo de sus tierras; b) compuesta históricamente, o caracterizada por la importancia de las estructuras coloniales y racistas del pasado junto a la idea de que la violencia estructural actual amenaza a las generaciones futuras; y c) compuesta espacialmente, o experimentada a través de un solapamiento (o compuesto) espacial cuando se da la convergencia de múltiples formas de violencia estructural dentro de los mismos paisajes y escenarios de vida, constituyendo verdaderos desplazamiento in situ. Cada uno de estos 
sentimientos, que se sienten de manera simultánea, tiene el efecto de volver claramente visible la violencia estructural , que se hace tangible tal cual es en la restructuración de los paisajes y escenarios de vida a pesar de los intentos discursivos de ocultarlos, enterrarlos y eliminarlos de los poderosos. Analizar las narrativas que utiliza la gente para criticar y enfrentarse a esa violencia provee herramientas conceptuales para analizar prácticas de resistencia contra la violencia estructural.

Palabras clave: Desplazamiento in situ, Hambre, Oleoducto, Estrategias de Visibilidad, Violencia Estructural.

\section{Introduction}

Outside the rural town of NangaEboko (hereinafter Nanga, as it is called by the people who live here) in central Cameroon, I saw the first physical evidence of the Chad-Cameroon Oil Pipeline: a semi-destroyed worker's base camp.

The camp was used temporarily during the pipeline's construction between 2000 and 2003 to house and feed migrant laborers, as well as to store the project's heavy equipment. With the air fresh and moist at the height of rainy season, I was visiting with two brothers, Daniel and Simon, who live in the homes nearest the remains of the base camp. Walking along the muddy path towards the brothers' groundwater source, we looked down the hill to the area where

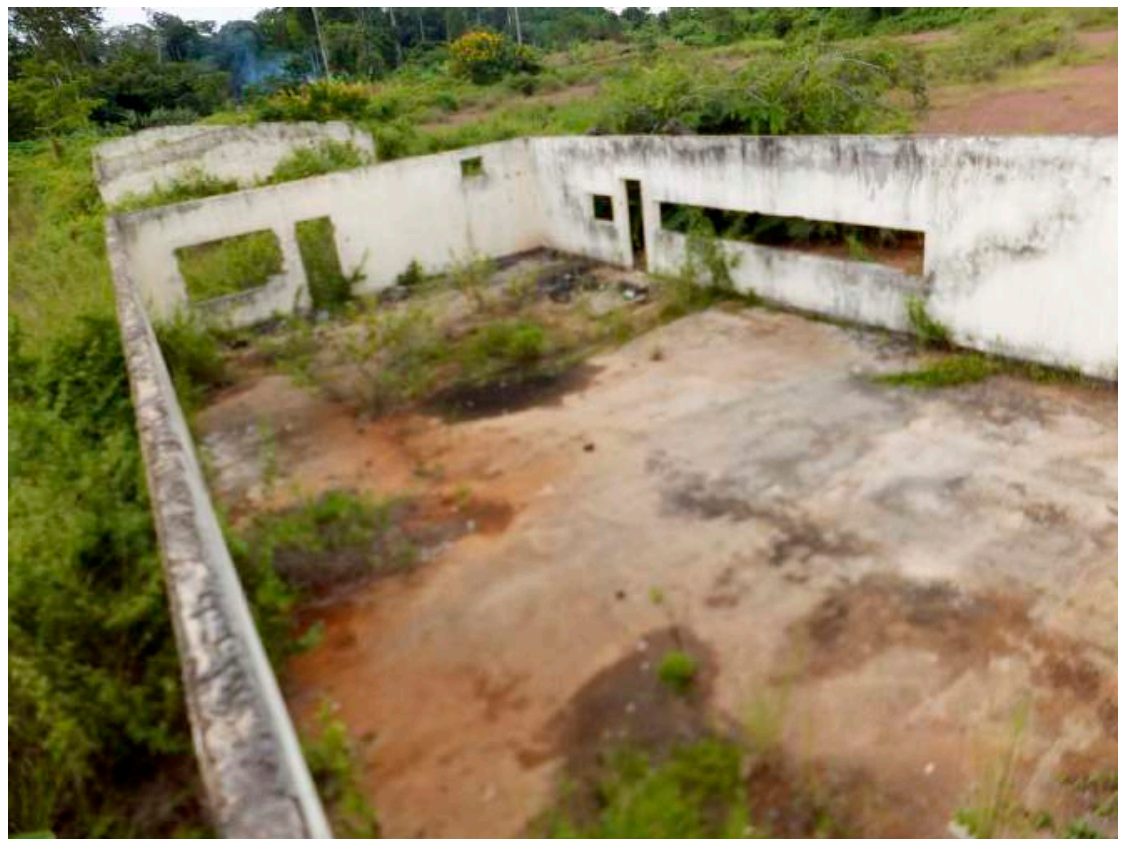

Figure 1. Abandoned building, former pipeline work camp, outside Nanga (Amber Murrey)

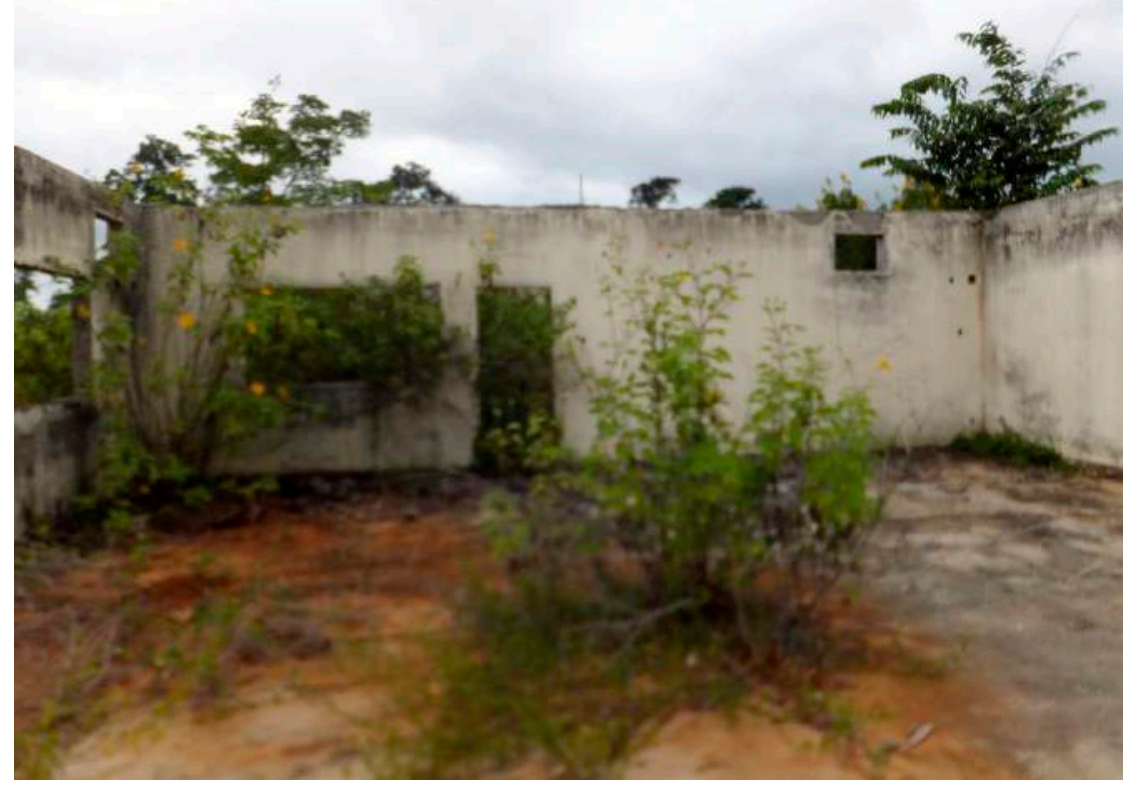

Figure 2. Another abandoned building, former pipeline work camp, outside Nanga (Amber Murrey)

the work camp once stood, now a vast expanse of exposed red earth, with a few scattered buildings (Figures 1 and 2). After the construction phase ended in the area, the roofs of the concrete buildings were torn off and the insides of the buildings were gutted, exposing the concrete foundations to the elements. The remaining concrete walls were heavily cracked and thick with underbrush. Glass shards and torn bits of linoleum were cast haphazardly on the ground. Anything of value that might have been left had long since been picked over. Consortium documents assert that, "after construction...the site of the construction camp would be returned to its natural contours and grade and topsoil returned to those areas where it was removed" (3.2.1.2 Esso Chad/Cameroon 1997: 3-6); this area had not been returned to its natural contours. 
The brothers, Simon Akono and Daniel Nkouma, spoke at once, "You wouldn't know it ever existed, but the work camp was like a town. It was bigger than the town, even - it moved." "The abandoned buildingsonce the offices, sleeping quarters, ablution units, laundry units and recreation hall-were all that remained above ground. Later, in Nanga, I was told that the heavy equipment used during the construction phase was demounted and buried there. To the people who believe this story, the place is a burial ground.

We by-passed the camp on our way to the men's post-pipeline water source, walking along the large road, which was wide enough for two vehicles to pass easily despite the almost complete lack of vehicles in Nanga (where bensikiners ${ }^{2}$ or motorcycle taxis predominate). The road was built to facilitate the work along the pipeline, but is now used by local foot and motorcycle traffic, as well as logging rigs. We left the main road as it split off to a footpath, leading down to a small ravine. My rain-boots slipped several times on the muddy rocks and I wondered at the technique and skill that one would need to carry a bucket of water on the way back up.

Before the pipeline, the family used a communal well near the work camp. That well had been destroyed

1 Some names have remained unchanged while others have been altered to preserve anonymity (each reflects the personal preference of the person). In a project concerned with recovering, uncovering, and creating space for people's voices, lives, ontologies and epistemologies, I felt that a discursive violence would be effected by effacing the names of those who specifically requested that I not do so. Many of the people whom I spoke with were adamant that their stories be heard, powerfully asserting their right to be known-not as a number, a euphemism, or a pseudonym, but as themselves. The literature on power and politics in ethnographic research almost uniformly espouses the need for anonymity, emphasizing the researcher's position of power and privileging the researcher's ability to consider the dangers of revealing people's identities. In this case, dismissing people's demands to have their names recorded would be a discursive injustice. There is no indication of which names have been changed for anonymity and which have not.

2 Following de-colonial critiques of linguistic Anglocentrism, non-English words are not italicized, not placed in quotations, and not visually set apart from English here. The visual practices of italicizing or isolating non-English words contribute (even inadvertently) to colonizing projects, labeling non-English languages as aberrant, exotic, or Other. during the pipeline's construction and COTCO (the Cameroon Oil Transportation Company), the private company in charge of overseeing pipeline operations in Cameroon, resolved to provide them with a replacement. We arrived at the end of the trail; the brothers showed me the replacement well. It was faulty, now nothing more than a solid concrete form, slick with mud and un-use. Their family gathers rainwater when they can, the brothers said, otherwise they collect water from where it seeps from the forest floor, just footsteps from the faulty well.

In Cameroon, water-related illnesses, and the parasitic diseases that thrive in standing water, are everyday threats. Onchocerciasis, a parasite transmitted through the bite of what are locally called les moutmouts (a black fly of the genus Simulium), can cause blindness. Months later, I was told by people living in the villages around Kribi, approximately 450 kilometers from Nanga, that the wind tunnel created by the pipeline right-of-way facilitated the spread of les moutmouts to the Kribi area, where they had never before been a problem. There are reports that a number of illegal cost-savings practices were used during the pipeline's construction, including the filling of pipeline trenches with "cement bags mixed with cement and topsoil" instead of the more environmentally safe gabion bags (wire baskets) filled with stones to protect the pipe (Keenan 2005: 402). ${ }^{3}$ Filling the pipeline trench with cement and topsoil causes cement leeching and washout, polluting water sources along the right-of-way with calcium hydroxide (Keenan 2005).

The older brother, Daniel, smiles as he shakes his head. For three years he has struggled with the local administration and COTCO to resolve the problem of access to clean drinking water. Daniel is unemployed and, like many Cameroonians, is adept

3 These reports are further substantiated through the testimony of Alan M. Dransfield, a former ExxonMobil Engineer who was terminated from the project in 2002 for objecting to what he calls the pipeline's "myriad of H\&S (Health and Safety) violations," including failure to install Emergency Shut Down Valves at all major river crossings, insufficient pipeline coating, testing failures, trench backfill violations, welding violations, and an improperly designed and installed fiber optic cable (interview with Alan M. Dransfield, by Djamil Ahmat 2014). 
in se débrouillage (managing lifetime-unemployment with temporary jobs in a variety of sectors). During the construction period, he was hired temporarily as a "room boy" to clean the worksite dining hall, wash latrines, and dispose of garbage. During the "moment of the pipeline" (the brothers' term for the period of pipeline construction), people jokingly and optimistically called themselves "Americans" because, it was believed, "dollars" would "pour" into the town from oil wealth. The construction period brought a brief but unprecedented influx of cash into Nanga, as subsistence farmers and small-scale commercial farmers were compensated for the destruction of crops, hundreds of migrant laborers consumed local goods, and local men (those employed during construction were almost exclusively male) were employed in temporary labor positions.

The younger brother, Simon, worked "in the ground" laying pipe. As he spoke, he was visibly agitated, waving towards his clothes, dusty and worn, with sizable holes in both trouser knees. Having just returned from the forest, where he taps matango (palm wine), he had his machete in hand. He used it to point at his body, waving the machete from his toes to his head. "Regarde-moi," he said, "On se retrouve dans la vieille époque, avec toute l'ancienne misère" (look at me-we find ourselves in the olden days, with all of the ancient miseries). He used his body and his clothing as an indication of the pipeline's cost to the landscape and to people's bodies, inscribing his body with the history of the pipeline.

As Simon and I spoke, Daniel walked along the edges of the road to avoid sinking into the thick red mud in his blue plastic flip-flops. He stopped to reiterate what his brother said about the miseries of "ancient times," showing me his puffy right eye. His sclera, or the white of his eye, was a vivid red. He wiped at it periodically with the back of his hand, blinking quickly. As we walked back up the hill towards their homes, we grew quiet, and I didn't ask any more questions. We reached the top of the hill, where a group of neighborhood children were playing. They stopped to hug arms and laugh at me, the sunburned ntangan. They ran towards us, giggling and jumping on the roadside. The air was heavy with the coming rain as we said our goodbyes.

\section{Outline of arguments}

Daniel and Simon's account reveals some intersections of the palpable forms of violence brought about through the construction, implementation, and everyday operations of the Chad-Cameroon Oil Pipeline as well as how these are compounded by additional ecological and structural violence(s) (Figure 3). ${ }^{4}$ People's narratives along the pipeline merge the experiences of deforestation, land dispossession, pollution and contamination of groundwater, the spread of the moutmout fly, and so on-experiences which have been mostly analyzed in isolation in academic scholarship on the pipeline. A focus on how these forms of violence overlap is meaningful in terms of understanding the experiences of the continuities of structural violence. By focusing the conceptual lens narrowly on one form of violence, we overlook mutually constituting forms that simultaneously configure landscapes and lifescapes. In this framework, instead of conflating discrete forms of violence within one rubric, we might speak to the experiences of structural violence in Nanga and Kribi as one of an expansive matrix of land dispossession, displacement in-place, and ecological destruction.

The concept of structural violence dates back to Johan Galtung's (1969) work on social position theory, as he developed an holistic lens for the study of social inequality. Influenced by Latin American liberation theologians, Galtung broadened the conceptual lens of violence by arguing that the dominant focus on direct violence-i.e. those violence(s) with precise beginnings and ends as well as clearly identifiable agents - is a restricted focus that omits the structures that frame physical violence as well as the ways in which institutions and institutional actors inflict violence. Drawing inspiration from Antonio Gramsci's (1982) analysis of how ordinary people (or "organic intellectuals") look at and describe political power, combined with critical geography's focus on

4 Officially titled the Chad-Cameroon Petroleum Development and Pipeline Project, the name has been shortened here to reflect its more common nomenclature. 


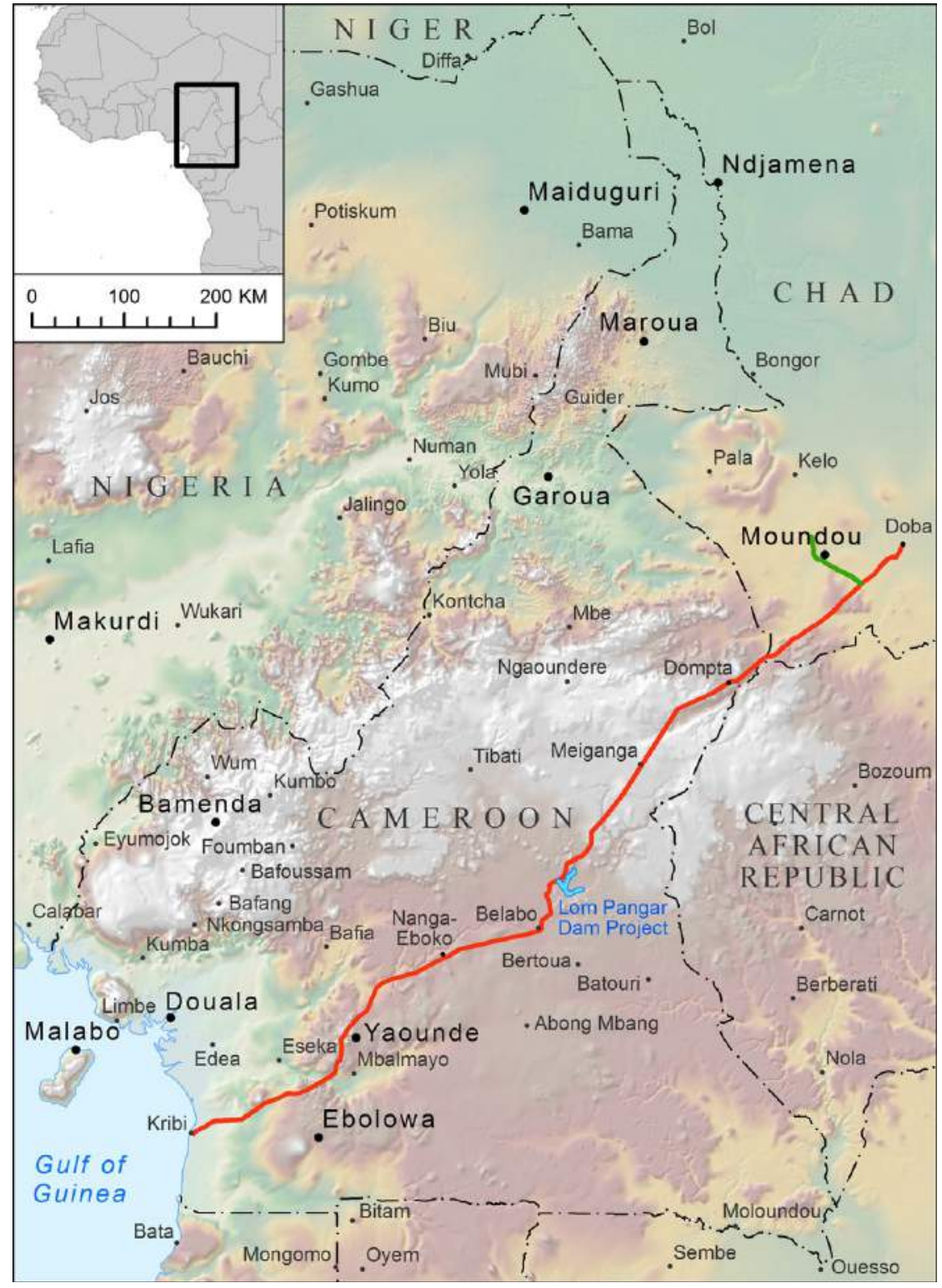

Figure 3. Map of the Chad-Cameroon Oil Pipeline (Amber Murrey)

the cognitive and embodied experiences of land dispossession and "displacement in-place" (Magaramombe 2008; Nixon 2011; Mollett 2014). ${ }^{5}$ Along the pipeline, structural violence is experienced as "displacement in-place," as access to safe drinking water and agriculturally fertile land is severely restricted, leading to illness, and aggravating hunger. Displacement in-place is a form of displacement-through-abandonment, as large-scale ecological damage destroys people's homes, landscapes, and livelihoods without displacing them far from it (physical displacement did happen in some places along the pipeline, at short distances; most land dispossession occurred as plantations were destroyed and familial/communal land was appropriated). Instead of displacing people from their land, the pipeline transformed the landscape, leaving them displaced-athome with contaminated water sources, soil erosion, deforestation, and oil spill pollution, as revealed through narratives of hunger (from soil erosion and decreased crop yields), illness (from polluted, contaminated, and destroyed water sources), and environmental uncertainty (Figure 4). At the same time that the landscape is dramatically changing and people are psychologically attending to potential disaster, mobility is constrained by local

material, lived, and embodied experiences (Castree et al. 2010)_including the emphasis on the "historical geography of material practice[s]" (Harvey 1996: 183) - I outline a re-articulation of the theory of structural violence by focusing on people's interpretations and experiences along the Chad-Cameroon Oil Pipeline.

One experiential marker of structural violence is the embodied struggles and physical pain(s) resulting from structural forms of violence. These are expressed along the pipeline through gendered narratives of hunger and illness, overlapping and arising out of police, the gendarmerie, and COTCO security guards.

5 I have been unable to determine the precise roots of the concept "displacement in-place" (also displacement-in-place or displacement in situ); it emerged in the early 2000s in the literature on development displacement as a means to expand theories of displacement to include non-physical forms. The earliest piece I located is from a paper presentation given by Magaramombe in 2008. Nixon (2011) and Mollett (2014) articulate variations of the concept. Godfrey Magaramombe (2010: 364) articulates displacement in situ as the "material and socio-economic losses without enforced movement to different places" or the "social dimensions of displacement beyond physical uprooting." Building on similar ideas, Sharlene Mollett (2014: 4) explains, "Much displacement does not involve physical movement but takes the form of constraints on livelihoods and cultural practices." 


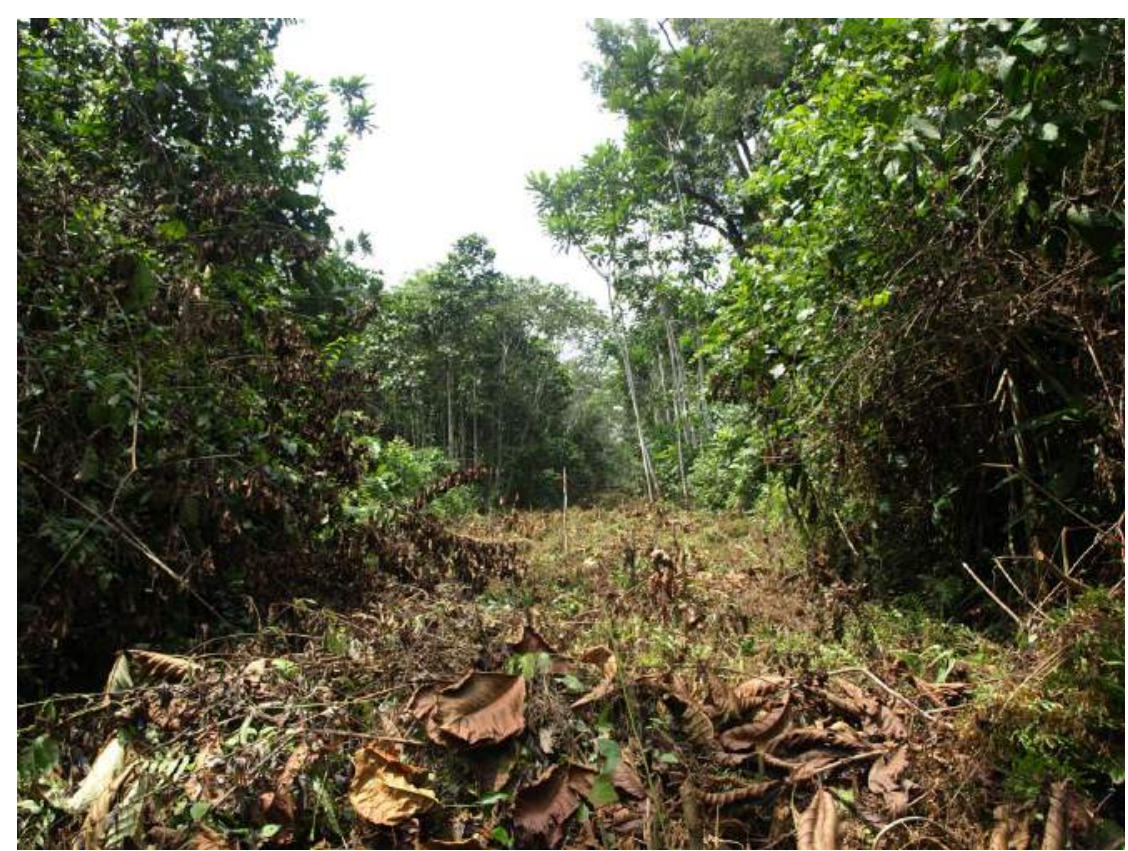

Figure 4. Wind tunnel along the pipeline right-of-way, near Kribi (Amber Murrey)

A second experiential marker of structural violence is its historical persistence. As structural theorists illustrate, socio-spatial relationships are historically rooted and stretched over time (Giddens 1984). As such, theorists of structural violence, including Galtung (1969), Paul Farmer (2004a, 2004b), Rob Nixon (2011), and Akhil Gupta (2012), agree that this violence is a constant rather than episodic. Nixon's (2011) notion of slow violence emphasizes the broad temporal and spatial operations of structural violence in the present and towards the future, employing the term as a means of highlighting the "slow moving mutations" of ecological damage and disaster that accompany large scale projects, such as Shell Oil's extraction in the Niger Delta. Nixon explains that, "time becomes an actor" in the operations of slow violence. While Nixon emphasizes the slowly unfolding nature of structural violence into the future, Farmer (2004a, 2004b) emphasizes the historical rootedness of this violence in the past, remarking that the violence of slavery, the plantation system, colonialism, patriarchy, and Eurocentrism set the stage for contemporary webs of structural violence by providing the ideological legitimacy, the racial, economic, and gendered hierarchies, as well as the property regimes through which structural violence unfolds. Along the pipeline, the historical duration of structural violence is illustrated in the compounding accounts of pain across time and spatial scales, evidenced in people's powerful connections between the present and the past, drawing from social memories and consciousness of colonialism, slavery, and past exploitations as a means to characterize the lived experiences of life along the pipeline, described as "encore une autre déception" (yet another deception) or using a language of witchcraft to characterize COTCO personnel and the unseen decision-makers behind the pipeline's implementation (Murrey 2015). Moreover, women and men are impacted unevenly by structural violence. Along the pipeline, for example, the oil consortium's reimbursement mechanisms failed to recognize the agricultural and medicinal contributions of women's crops (e.g., cassava, yams, groundnuts, medicinal plants), instead reimbursing people and families for the loss of crops deemed to be of market value (women's crops are traditionally consumed by the family or locally). The destruction of nearby wells and boreholes during the pipeline construction increased the daily walking distance for women and children to collect water for household activities. An influx of temporary workers created new and increased demand for sex work and an attendant exposure to sexually transmitted diseases; at the same time, the consortium almost exclusively employed men, exacerbating income inequality between men and women.

A third experiential marker of structural violence is its spatial compoundedness, or the coalescence of simultaneous ecological, environmental, social, gendered, dispossessing violence(s) in the same place. The re-articulation of structural violence offered here involves an expansion of our understanding of its experiential effects as spatially compounded: in this sense, the pipeline participates in and aggravates preexisting structures of violence, as well as perpetuating new forms.

This triad of structural violence indicates the ways in which structural forms of violence are often hyper- 
visible, in spite of their (apparent) normalization or banalization, because they are widespread. People's narratives reveal, contrary to much of the scholarship on structural forms of violence, which describes such violence as invisible, silent, or unseen, that structural violence is often acutely visible for people living within structurally violent nexuses. An awareness of this hyper-visibility has significant implications for intellectual projects of social justice that critique, and seek to combat, structural forms of violence: instead of focusing on the invisibility of structural violence, as has been the academic trend, we might consider the ways in which structural violence is acutely visible and the languages used by people to critique, understand, and engage with such violence.

At the same time, this analysis engages with a principal criticism of the theory of structural violence: the argument that structural violence is vague and capacious, to the point of rendering violence "ubiquitous" or everywhere (Wacquant 2004). However, all structural social phenomena are by definition widespread: structural phenomena are built into the very fabric or foundation of social networks, interactions, and exchanges. This is not to assert that all forms of structural violence are uniform or that structural violence entraps people and landscapes uniformly. Rather, focusing assiduously on "one" violence dismisses the systemic (by this I mean the complex and often contradictory, shifting power hierarchies between and within local, national, and transnational spatial scales) institutional realities (always permanently changing form, method, property, and process) which precede and supersede the oil pipeline. So, structural violence is not a theoretical articulation which fails to differentiate or distinguish "important" differences between various forms of violence. Instead, it is a theoretical articulation which actively refuses to be complicit in the historical and geographical de-contextualization and artificial separation between forms of violence that are united in their enactments at a distance from those harmed, through multiscalar transactions that remain out-of-sight, which are implemented to ensure enormous financial and economic profit fro transnational capital.
Furthermore, by rooting my analysis in a specific temporal and spatial context, I hope to demonstrate that structural violence is a coherent and useful conceptual framework for illustrating the intersections among discrete patterns of violence, including the ways in which different violence(s) are compounded as they are experienced in everyday life. As a broad but coherent force, I argue, structural violence is capable of engaging with various discrete forms of violence simultaneously; as such, it is a holistic framework capable of understanding how multiple interacting forces are felt simultaneously. Analyzing these in isolation fails to engage with the immensity of the scope of the violence and performs a de-contextualization that can be politically disempowering.

The use of narrative is of central importance here; much of the scholarship on the pipeline has been conducted at the policy-level, through an analysis of the interactions between the World Bank, the oil consortium, the national governments of Chad and Cameroon, and nongovernmental organizations (NGOs). Notable exceptions have been the long-term and ongoing survey-based research among 120 households in three sites in southern Chad, with a focus on health impacts by Siba Grovogui and Lori Leonard. Joyce Endeley and Fondo Sikod's (2007) surveybased research illustrates the depth and complexity of struggles among the state, the community, and the individual over land ownership and resource control in Cameroon, arguing that the pipeline has exacerbated poverty in towns along the pipeline right-of-way. Endeley (2010) highlights the intersections among land dispossession, land tenure, and gender, arguing that because of the male dominated character of the oil industry, women are super-marginalized through the pipeline project: as non-beneficiaries (without access to employment or training opportunities) as well as by gendered land dispossessions and heightened exposure to environmental damage.

This scholarship importantly highlights the failures of project management and implementation. However, the reflections and narratives of people along the pipeline have remained at the periphery of academic discussions. My approach merges feminist, decolonial and critical geographical standpoints 
conscious of the geopolitics of knowledge creation and critical of a monolithic, single-voice, and positivist voice; instead, I approach narrative as a mode of knowing and narration as a mode of communication within social science (Cesera 1982; Arguedas 1985; Bruner 1986, 1990; Polkinghorne 1988; Reck 1993). This project was undertaken with a geographical development methodology (Raghuram and Madge 2006) that receives guidance from the concerns and experiences of the people involved in the research, and uses film, and the subsequent screening of film, within the ethnographic context as a means of extending and facilitating people's participation, so that the feedback of community members on the project's conclusions feature significantly. I lived in Kribi and Nanga between July 2011 and March 2012, during which time I interviewed city mayors and pipeline employees, spoke at length with community members, and accompanied people to social gatherings, agricultural fields, and other places of work. ${ }^{6}$ I conducted an extensive review of newspapers and periodicals (including oil-funded marketing prior to the pipeline's construction and local commentary on potential outcomes of the project) and pipeline documents (from ExxonMobil, COTCO, and the World Bank), as well as nonprofit reports written on behalf of people along the pipeline (such as the Forest Peoples Programme and the Centre Pour l'Environnement et le Développement in Yaoundé).

I work from a consciousness of my place in the longue durée of colonial violence, with an attention to people's narratives alongside an acknowledgement of my incomplete access to them. My intent is to elucidate some of the ways that structural violence is experienced, navigated, and spoken about by those who live in Nanga and Kribi, with an acknowledgement of my presence within the setting where the

6 As this is a decolonial project-or a project that seeks to join the ongoing collaborative effort to decolonize knowledge and further challenge the mechanisms of knowing á la scientism-I distance myself from terms like "the field," "the interview," "the informant," and "the research subject." These historically- and spatially-charged categories artificially de-privilege non-academic spaces and people as "knowable" or "researchable" for an empowered researcher, while limiting people's contribution to "knowledge" according to what is perceived to be important according to, and therefore pursued by, "the researcher." narratives emerged. This humble consciousness of my place is reflected in the moments where I highlight the knowledge that I don't have, and when I trace the moments in which my friends in Cameroon reveal how they might see themselves or me. This is part of working against the established tendency to erase the researcher in ethnographic writing - a convention that seeks validation for "what is known" by erasing the author (and therefore hiding the author's position in the research); Colombian philosopher Santiago Castro-Gómez (2007) calls this dominant convention of academic writing the "hubris of the zero point." At the same time, I do not focus centrally on my identity, as the point is not to perform another Eurocentrism by re-centering myself in the narrative. Emphasizing the ways of knowing reflected in people's narratives illustrates the brokenness or non-totality of structural violence, while also stressing the ways that people discuss, name, experience, and are conscious of forms of violence.

\section{Background: Displacement in-place along the pipeline}

The Chad-Cameroon Oil Pipeline is the largest private construction project ever undertaken in Africa (Grovogui and Leonard 2007). The pipeline pumps approximately 78,000 to 105,000 barrels of crude oil each day from the Doba Basin in southern Chad along 1,070 kilometers of carbon steel pipe, cutting across the landscape of Cameroon from northeast to southwest. The pipeline's marine terminal is located near Kribi, where an offloading vessel is situated 12 kilometers from the shoreline; from here, the crude is loaded onto tankers and exported for refining and, ultimately, traded on the global market.

With the construction of the pipeline between 2000 and 2003, forests, vegetation, farmlands, ancestral lands, and homes were destroyed along a 30 to 50 meter-wide corridor. A material land space the size of the Benelux (Belgium, the Netherlands, and Luxembourg) was expropriated-surveyed, staked, cleared, and graded-in Cameroon and southwestern Chad for the anticipated 30-year lifespan of the project. Thousands of families were dispossessed of land. Displacement in-place calls attention to the 
violent reorganization of space through interrelated and intersecting social and ecological processes, as people are not physically displaced from the land, but the land is transformed around them. People in Nanga and Kribi have been displaced-at-home with contaminated water sources, soil, and coastal erosion, deforestation, and oil spill pollution. Ecological destruction of land, loss of access to land, displacement in-place, and land dispossession are all kinds of violent spatial transformations brought about by the Chad-Cameroon Oil Pipeline.

The oil consortium, led by the World Bank, promoted the project as a "development" project that would ensure the use of oil profits for projects for local wellbeing on the Chadian side of the project. The Bank implemented a number of spending mechanisms for oil revenues in Chad; these were violated almost immediately. No such spending limitations were imposed on Cameroon. The oil-for-development discourse failed in both Chad, where President Idriss Déby spent $\$ 3$ million USD of the project's signing bonus on arms to fight militias in Northern Chad in the name of "state security" (Grovogui and Leonard 2007), as well as Cameroon, where the uses of project profits have never been explicitly named. The development discourse finds few echoes in people's narratives of the pipeline in Nanga and Kribi.

People living in rural and peri-rural areas, like those in the villages around Nanga and Kribi, are exposed to what Ngouo Ngali called "an enforced waiting for death" ("nous sommes obligés d'attendre la mort"). Ngali, the chief of Mpango, the village nearest the pump reduction station outside of Kribi, described the risk of illness that accompanied the spread of the moutmout fly to the area. She said,

Now we are obliged to wait for death. There was one case that I know of, a man temporarily lost his vision and still has a white scar on his eye because the fillet rose to his eyes and caused cataracts. I expect this more and more. I know it happens in different locations... the point is that we are progressively losing life. The risk [of losing life] is there all the time.
The engineers of the Chad-Cameroon Oil Pipeline sought to avoid densely populated urban spaces so as to reduce the number of people incorporated; this also meant, however, that Cameroon's poorest and most politically disenfranchised people would be the most endangered. Eighty-nine percent of Cameroon's poor live in rural areas (ECAM Three 2007). This has meant that the rural poor, already politically and economically marginalized within Cameroon, have been disproportionately incorporated into the project.

On the coast of the Atlantic Ocean, the population of the community of Kribi is 70,565, 90 percent of whom are under the age of 50 (information provided by the Mission d'Etude Pour l'Amenagement de l'Ocean in Kribi, 2012). With picturesque beaches, waterfalls, and historical monuments, Kribi is a foremost tourist destination in Cameroon. The principal economic activities are artisanal fishing, tourism, logging, and hunting. Nanga-Eboko, with a population of 35,330, is the capital of the HauteSanaga (Upper Sanaga) department within the Centre Province of Cameroon. The Sanaga River, the longest river in Cameroon, splits the community from North to South. The community of Nanga includes 103 villages, each of which has a local chief who is consulted or informed of developments within the communities, including information about the implementation of the Chad-Cameroon Oil Pipeline. The villages are grouped into separate second-degree chiefdoms, supervised by a préfet, who is overseen by a governor (information provided by Kribi's Préfet in 2011, Magloire Abath Zangbwala). The chieftaincies were structured as local proxies during the colonial period to sub-divide power and ensure administrative duties were carried out according to the German and later French colonizers (Owona 1973; Guyer 1987; Quinn 2006). The system of chieftaincies remains in place today; this colonial inheritance was integral for the pipeline's land appropriation, as local chiefs played integral roles as go-betweens, calming and reassuring people that the pipeline would be beneficial. This created post-construction tensions, as chiefs now feel betrayed by COTCO representatives, at the same time that people are suspicious of their chief's involvement in the project. Likewise, the colonial land tenure system-which established land as property for men 
and deemed all non-deeded land, even if historically occupied, as state owned-remains at the heart of current land policy in Cameroon and continues to facilitate land dispossession in the name of the state.

\section{Tangible violence in-place}

While accompanying Rosa into Nanga town one afternoon in early September 2012, she explained that her day starts at 6 in the morning. While her mother and sister-in-law generally manage the family's small plot, Rosa ventures to the market to purchase meat-mostly bush meat, such as porcupine, from the other side of the Sanaga River - to cook for migrant laborers. She goes with several women to prepare food for the men who work at the Chinese-owned gravel pit nearby. She doesn't sell to the Chinese bosses, she explains, as they have their own cooks. She takes her five-month-old son, wrapped in pagne on her back. Rosa has three children, her two eldest live in Douala with her sister and brother in-law. Her 16-year old daughter is finishing high school next year; she hopes to be a nurse. With her red umbrella in hand to shade her baby boy from the bright midmorning sunshine, Rosa was a striking figure. As we walked through her neighborhood, she greeted most of the people walking, including the children in light blue school uniforms. "Is that you, already grown up like that?" she teased a young girl. "Is it the hour of prayer already?" She asked a man. She laughed softly to me, "They'll all run home and tell their friends that they said hello to a white person - and that the white person said hello back."

When Rosa was 20 years old, the pipeline construction crews arrived in Nanga and she, like many of her family members and friends, believed that her life had changed forever. She was approached by a local man and offered monetary reimbursement to sleep with a "Colombian boss" from the ExxonMobil construction crew (a number of Colombian men were employed as welders along the pipeline route). At the time she was making money as a bayam-sellam or a revendeuse (a small-scale entrepreneur, usually a woman, who independently buys and re-sells goods). She would purchase accessories in Douala and selling them locally for a small profit. In the late 1990s and early 2000s, she could buy a pair of sandals in Douala for 1,000 CFA (approximately \$2 USD) and turn them for a profit in Nanga, selling them for 2,000 to 2,500 CFA ( $\$ 5$ USD). The flooding of the market with cheap goods, mostly imported from China and increasingly from Dubai, lowered the value and raised the availability of such items; consequently, Rosa stopped selling things about 8 years ago. Around the same time, she was diagnosed with human immunodeficiency virus (HIV).

After the pipeline's passage, the rate of HIV and acquired immune deficiency syndrome (AIDS) increased exponentially in the community, where the virus had not previously been a problem (Silverstein 2003; Endeley and Sikod 2007). The risk of increased rates of HIV and AIDS in villages along the pipeline route was a form of "collateral damage" for pipeline engineers, who anticipated the temporary increase in sex work with the influx of male migrant laborers (large-scale infrastructural projects nearly always trigger increasing rates of sexually transmitted diseases). According to Madame Lizette, a nurse specializing in the virus, who was recruited for the local hospital, measures to mitigate the problem were only taken after the passage of the pipeline in Nanga. Now, Rosa fatigues easily and she has regular hospital visits to contend with. Rosa is also responsible for her younger brother, who was forced to quit school after a sudden and unexplained itching in his foot led to the gradual loss of all feeling and eventually developed into filariasis and elephantiasis of his entire left leg. His illness could be a result of a number of neglected tropical diseases (so named because they are acutely understudied, lack vaccines, and affect only people in tropical zones, where pharmaceutical companies do not earn large profits), including podoconiosis (an abnormal inflammatory reaction to mineral particles in red clay soils) or wuchereria bancrofti (a parasitic roundworm spread by mosquitoes).

Our conversations often revolved around hunger, as Rosa worried about having food for herself and her family. She laughed about "les white stars" on TV (although francophone, she said "white stars") who, she said, would surely be jealous of her thin frame. On another occasion, her brother sat eating a plate 
of boiled plantains and an avocado; she said, "le tchop des hommes célibataires" (single man's food). For Lizette, Tené, Jean, Simon, Daniel, and many others, hunger was described as a constant, nagging companion. According to Essimi Menye, Cameroon's Minister of Agriculture and Rural Development, chronic hunger affects one out of every two people in Cameroon (press conference 16 Oct. 2013). Child hunger is particularly pernicious, with Cameroon home to 44 percent of the chronically malnourished children in the 11-member Economic Community of Central Africa States (ECCAS). Twenty percent of Cameroonian children are underweight and more than one in four suffers from stunting resulting from nutrition deficiencies (UNICEF 2013).

For people living in the Equatorial rainforests near Nanga and Kribi, small-scale, rain-fed shifting agriculture is a mainstay of life. Small farming plots are arduously cleared from the thick rainforest growth and are cultivated in a two-field system of gender complementarity that dates back to the pre-colonial period (Quinn 2006: 15-18). In Nanga, men cultivate the esep (dry season field), producing plantains, cacao, mangoes, citrus fruit, avocadoes, and sugar cane. Women using a shorter hoe on afub owondo (smaller field) produce beans, groundnuts, maize, cassava, yams, potatoes, and other vegetables (Quinn 2006: 17). These small family-run plots are invaluable, contributing an estimated 90 percent of food consumed in Cameroon (World Food Programme 2012). Although only 13 percent of the land in Cameroon is arable, agriculture (including large industrial plantations) and forestry account for 62 percent of the workforce and 20 and 40 percent of the GDP respectively (World Food Programme 2012).

Cameroon was nutritionally self-sufficient until the early twenty-first century. However, after two decades of the neoliberal policy preferred by the World Trade Organization, the World Bank, the International Monetary Fund, and the government of Cameroon, and the development of export crops, food farmers have been under-supported or pushed off their land (DeLancey et al. 2010: 25). At the same time, changing weather patterns, land dispossession, soil erosion, deforestation, rural-to-urban migration, and industrial pollution come together to make farming more difficult than ever. In February 2008, popular discontent at the rising price of petroleum and food (primarily rice and bread but also tomatoes and meat), alongside a constitutional amendment by President Biya to eliminate presidential term limits, gave rise to a series of transportation strikes by taxi drivers and storeowners, effectively shutting down major cities, including Douala and Yaoundé for a week. ${ }^{7}$

If, as Jean told me in Nanga, "le terrain lá, c'est le ventre" (the land is the belly), cassava unifies the land with the belly in central Cameroon. Indeed, cassava is a symbol for the community in some contexts (Richards 1986). "If you take away the land, you have taken from us our food," Jean told me in Nginda, outside of Kribi. "We cannot ever forget that. So, everyday we think-forever-of that pipe.” People's narratives connected soil erosion, soil warming, and soil disturbances to chronic hunger, particularly in regards to the tubers consumed for immediate dietary needs.

Following the decline in the global price of cocoa and coffee in the 1980s, Cameroonians diversified agricultural production (which had continued the colonially-enforced system of monocropping, where farmers cultivate cacao, coffee, sugar, and other exportoriented crops exclusively), turning increasingly to cassava (manioc), a tuber and starchy carbohydrate, as a centerpiece in daily diets. As the mainstay of rural household subsistence, cassava is eaten in several different forms, including les batôns de manioc or miondo (cassava soaked in water, pounded into a paste, wrapped inside banana leaves, and steamed), le manioc simple (cassava sliced and boiled), and couscous de manioc or foufou/fufu (cassava flaked/ graded, dried in the sun, ground into a powder, and then turned quickly as it is added to boiling water).

\footnotetext{
7 The government responded by sending heavily armed gendarmes into the cities and setting up roadblocks to divide the major quarters. After mass arrests and the killing of an estimated 137 civilians (Amnesty International 2009), the protests were suppressed. The government conceded to continue petroleum subsidies (ensuring taxi fares remained low) but pushed forward with the elimination of term limits, allowing Biya to run for a sixth term in the presidential elections in October 2011.
} 
The leaves of the plant are consumed in sauces such as kpwem, a dish that is culturally important for the people of central Cameroon. The transformation of raw cassava into les baton de manioc (for sale at local markets and for transport to the markets of Yaoundé) is a principal source of revenue for women in Nanga. This money helps pay for daily expenses like transport, school, and other material needs.

In Nanga, cassava is consumed daily, alongside avocados, and groundnuts. Meat is consumed rarely, with bifaka or poisson séché (smoked fish) being a more accessible source of protein, particularly in the non-electrified villages around Nanga and Kribi. The overhunting of wild animals for bush meataccording to people in Nanga and Kribi, overhunting has been aggravated by the migrant laborers who come into town for large-scale construction projects as

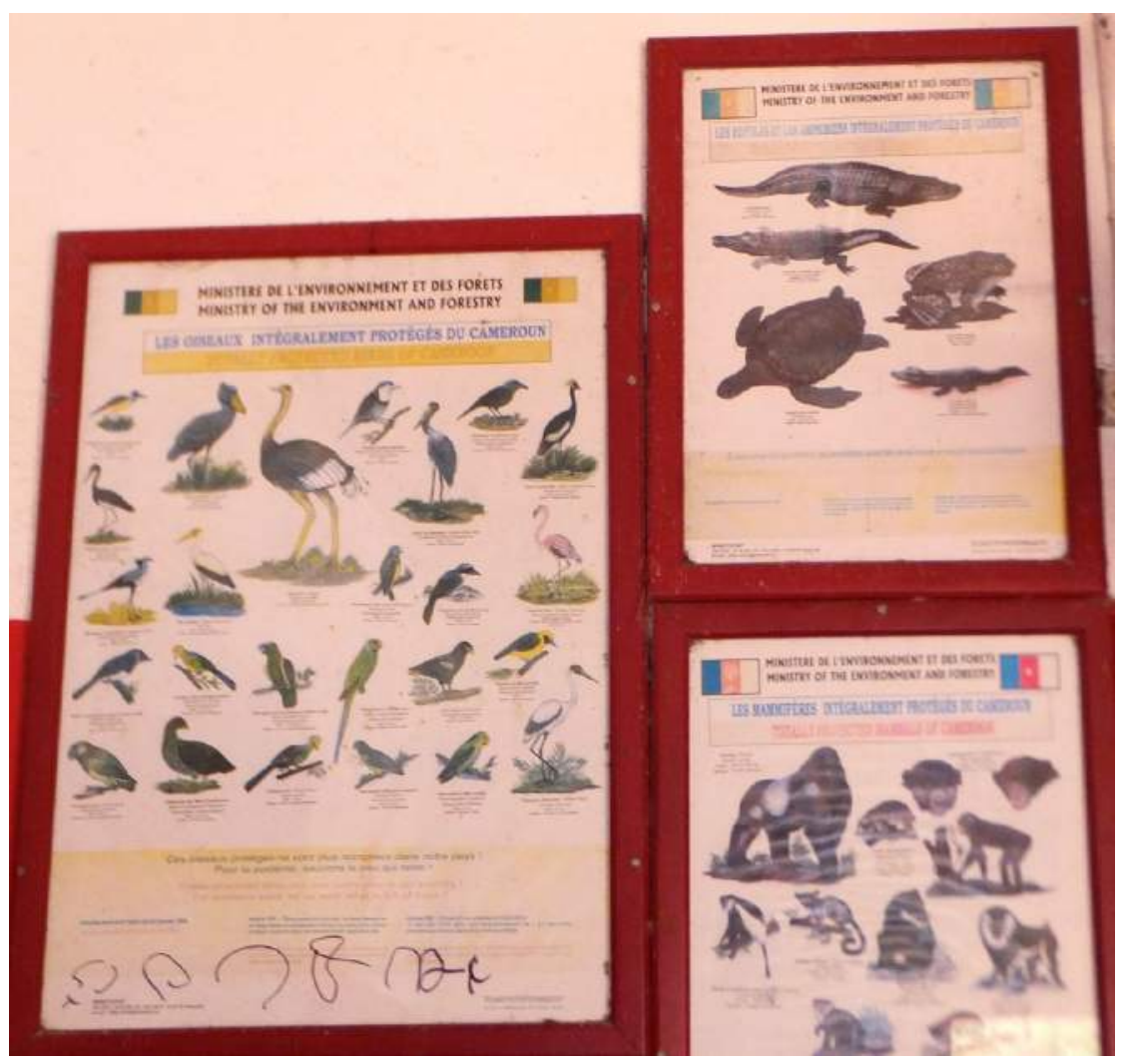

Figure 5. Sign at Nanga train station, indicating the area's endangered species (Amber Murrey) well as loggers (both legal and illegal, see below) — has depleted the forests on the Nanga side of the Sanaga River. The government has responded with a number of anti-poaching efforts, including random stop-andsearches of buses travelling from Nanga to Yaoundé (Figure 5). In this nutritional context, the importance of cassava cannot be overstated.

Cassava is vulnerable to even slight changes in soil temperature; this was emphasized repeatedly in discussions with farmers along the pipeline, who reported that, in the warm and abnormally moist soil along the pipeline, cassava rots in the ground before it reaches maturity. This means that cassava crops must be harvested early when planted along the pipeline right-of-way. Soil disturbances during the construction period (as forests were cleared and leveled) included the mixing of rock, concrete, and debris with nutrient rich topsoil. Root systems derive most of their nutritious components from the vital topsoil and, according to people's accounts, the topsoil was destroyed after the subterranean installation of the pipeline. Although the oil consortium reports that the topsoil would be "removed, stockpiled and eventually re-spread over the graded area" (3.2.1.2. Esso Chad/Cameroon 1997: 3-4), I was unable to locate photographic evidence that this was the case, and oral histories and cultivation difficulties in Nanga and Kribi refute the oil consortium's account. Testimony from ExxonMobil whistleblower, and former engineer of the Chad-Cameroon Oil Pipeline, Alan M. Dransfield, substantiates the communities' experiences of improper soil redistribution. Numerous accounts from construction employees in Nanga reiterate the seeming disregard for topsoil disturbances.

In Nanga, Maman Medgongo explained to me that, because she is afraid of an explosion or a fire along the pipeline, she abandoned her pre-pipeline farming plot. Although informed by COTCO representatives that she could continue to farm cassava and peanuts above the pipeline, she decided to leave the plot as she feared an ecological disaster. The once-fertile soil is now barren, she said, mixed with rock and concrete during construction. We were seated on wooden benches outside her home, in a compound shared 
with her son and his wife. A hen clucked nearby as Maman Medgongo periodically slapped at biting flies with a hand-broom made from the dried stems of palm leaves, tied together with a bamboo string. She explained to me that her new plot is farther from her home and that the distance increases her daily walk to work by 30 minutes. Cassava cultivation is labor intensive, with women often beginning their workdays before 6am and carrying heavy loads of firewood and produce. At nearly 70 years old, she cannot farm "les terrains pas touchés" (uncultivated forest land that has not been cleared). The section of land she now farms had been left to fallow by a younger farmer and as a result, she explained, her plot is over-cultivated and the soil has been stripped of valuable nutrients.

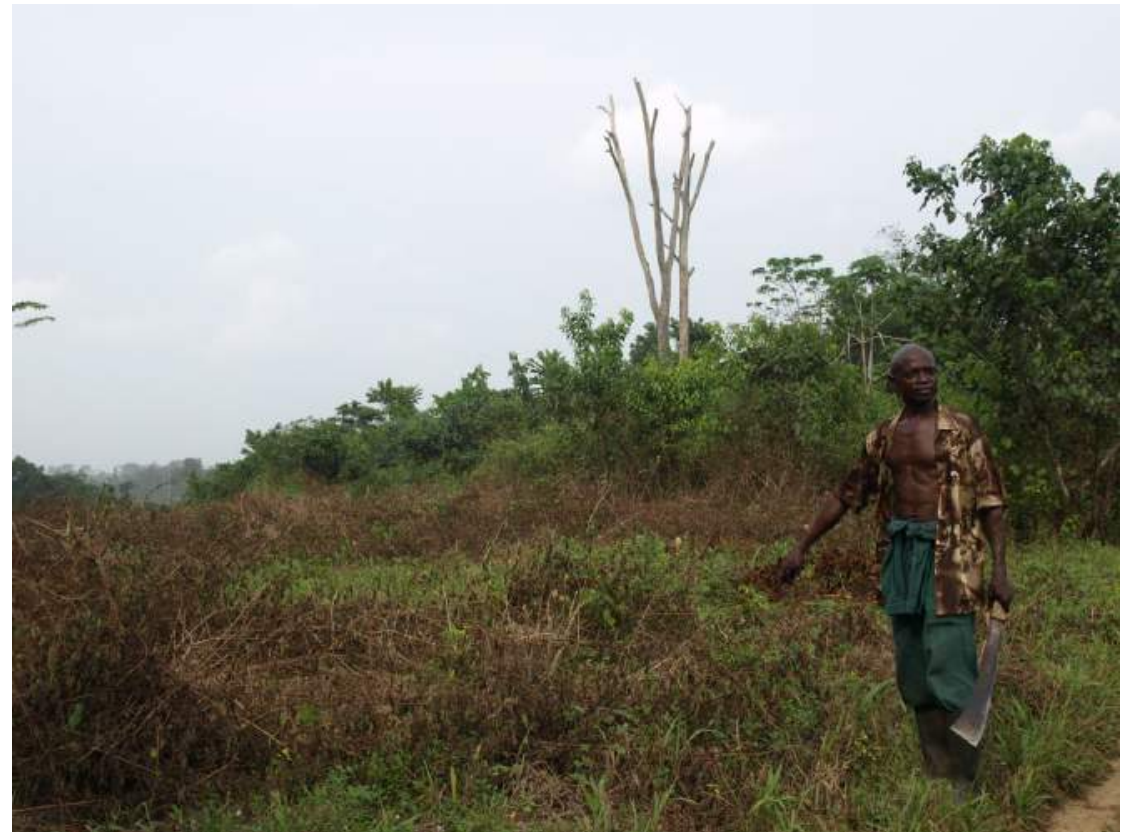

Figure 6. Pierre stands atop the pipeline right-of-way, the location of his destroyed plantation, near Kribi (Amber Murrey)
Since the pipeline has passed, the cassava is rotten.... we have famine since the pipeline.

In Nanga, COTCO representatives told people that they could continue to plant above the pipeline area but only growing crops with short root systems, such as groundnuts and cassava; this was not the case in Kribi, where COTCO apparently altered planting regulations after construction was completed (this is one indication of non-unified policies along the pipeline, where one community is told one policy and another is told something different). Ndgila André, in Mpango, a village outside of Kribi, explained the paradox of cultivation along the pipeline,

At first, they [COTCO personnel and community liaisons] told us that we could cultivate atop the passage [of the pipeline], but only those plants that were quick to mature. Then shortly after the construction [was complete], they told us that it is strictly illegal to cultivate along the passage. We know that they just made promises [of continued farming prior to the construction] to pacify people.

For these reasons, people emphasized greater hunger and declines in production following the pipeline's construction. As we stood atop the pipeline, in the location of his former plantation, long destroyed by the pipeline (Figure 6), Pierre told me,
People in the villages near Kribi and Nanga reported changes in growth patterns of cassava above the pipeline. In instances where women tried to continue cultivation after the pipeline's construction, I was told, tions.

The pipe is hot, it burns women's planta-

At 20 meters, the cassava is still disturbed by the heat of the pipe.
Since the pipeline has been installed, nothing grows well. We have no proof, but we know that is how it is. It hurts inside. It honestly, seriously hurts. But who will listen to me? Agriculture is how I live. It is how I feed my children and my grandchildren... For the loss of our food, I cannot call it reimbursement-I call it mockery. They mocked us.

Both Jean and Tené described hunger as the "first thought in the morning" and "the last thought at 
night." Hunger was less spoken about in Kribi, which has a healthy tourist economy and greater access to animal protein in the form of fish, although the fishing sector has likewise suffered after a large section of coral reef (important habitat for marine life) was dynamited during the construction of the pipeline. The impact on Kribi's artisanal fisheries is incalculable because oil consortium environmental baseline studies did not comprehensively gather fishing data (Schwartz and Nodem 2009). In Ebomé, outside Kribi, the chief told me,

You know, here on the coast, we fish to feed our children [but COTCO] broke our rocks that [used to] hide the fish. They said they would build an artificial rock habitat but that never worked. Then, the petroleum that leaks in the ocean has already ran off many, many fish.

The destruction and contamination of groundwater abstraction points (also called wells, bore holes, or water sources) during the construction of the pipeline was one of the most frequently noted embodied struggles arising from the structural violence of the pipeline (Figure 7 and Figure 8). Seven families, three in Nanga and four in Kribi, showed me contaminated, destroyed, or unsafe water sources caused by the pipeline (Figure 9 and Figure 10). During construction, groundwater sources or boreholes were destroyed alongside the right-of-way on a large scale; these sources were then either inadequately replaced or were not replaced at all. The destruction and contamination of pre-existing water sources was compounded by an almost unanimously reported ineffective wellreplacement procedure, as wells did not comply with technical standards. As such, all of the replacement wells that I was shown are today abandoned. People traced material vulnerabilities_-intestinal parasites, amoebasis, and dysentery - to the contamination of water sources. Shallow, stagnant groundwater is susceptible to bacteriological pollution, which has an immediate and marked impact on health. In a discussion with seven women in the village of Bilolo outside Kribi, one woman emphasized,

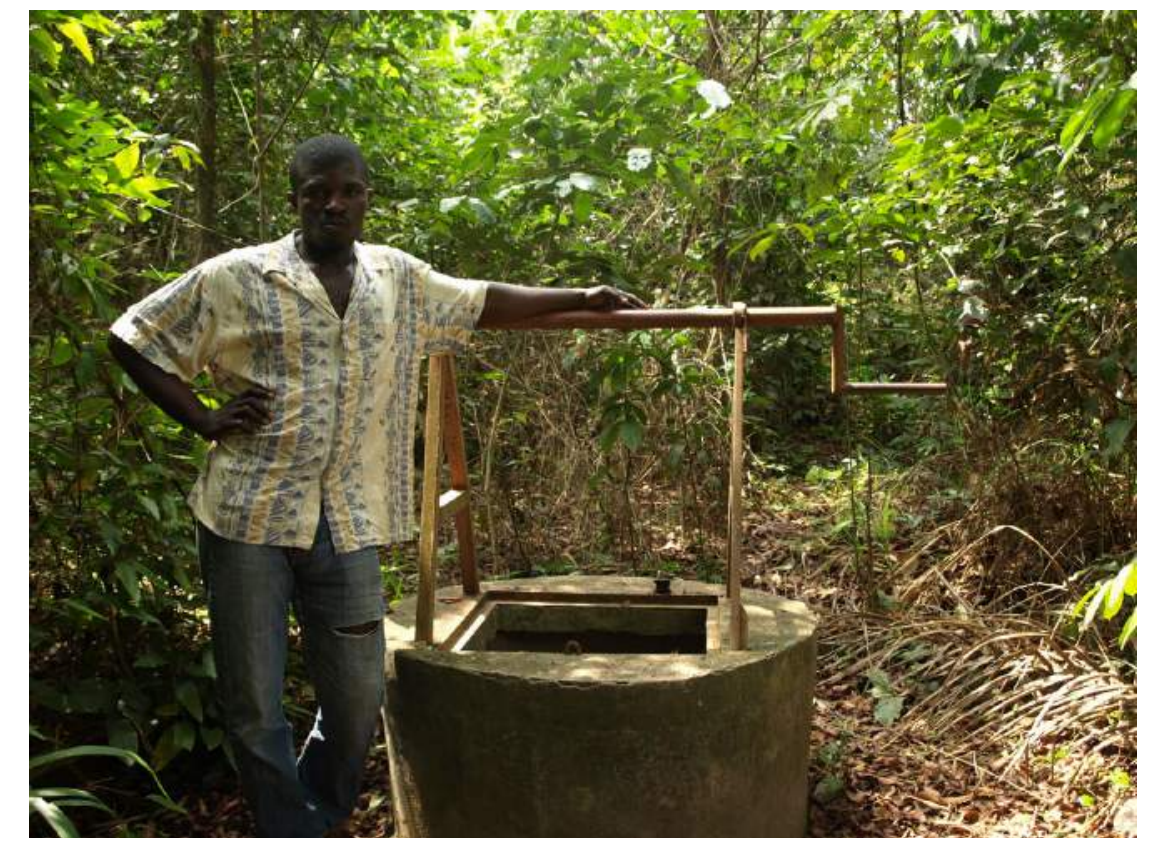

Figure 7. Non-functioning well that was built by COTCO as reimbursement when a borehole was destroyed during pipeline construction, Mpango (Amber Murrey)

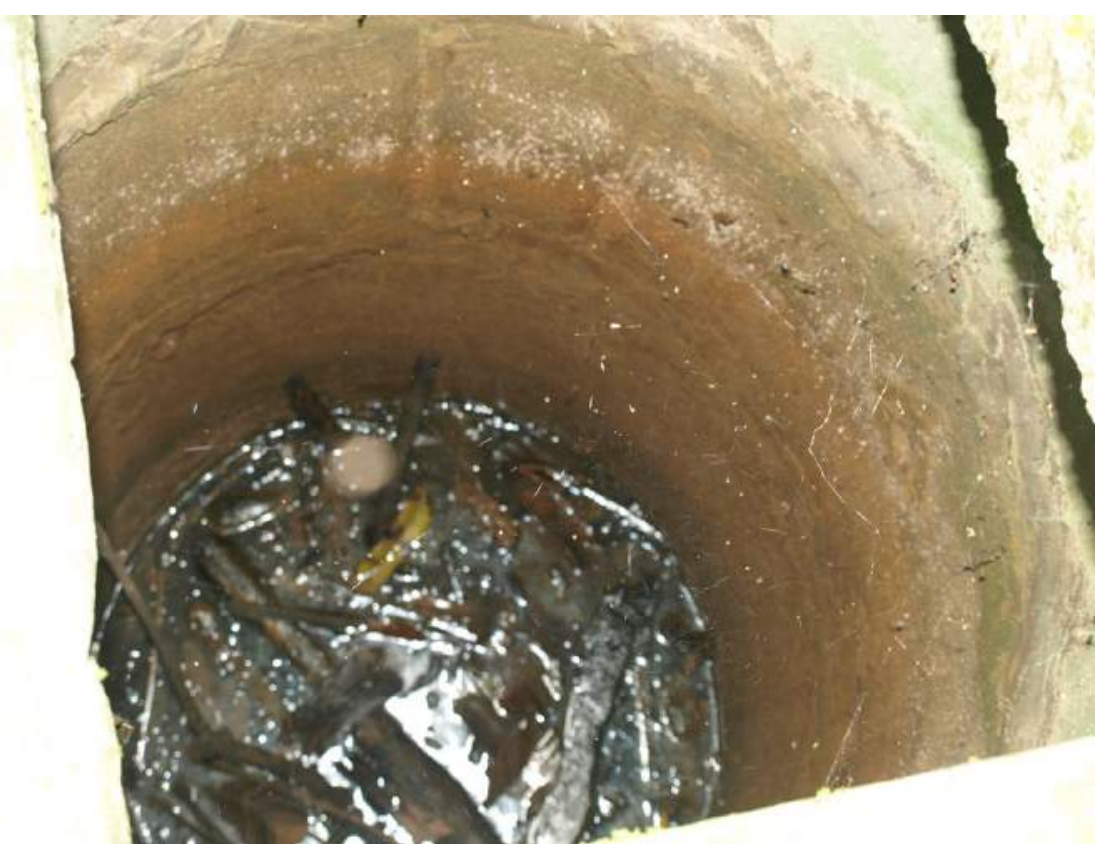

Figure 8. Looking down into a non-functioning well that was built by COTCO as reimbursement when a borehole was destroyed during pipeline construction, Mpango (Amber Murrey) 


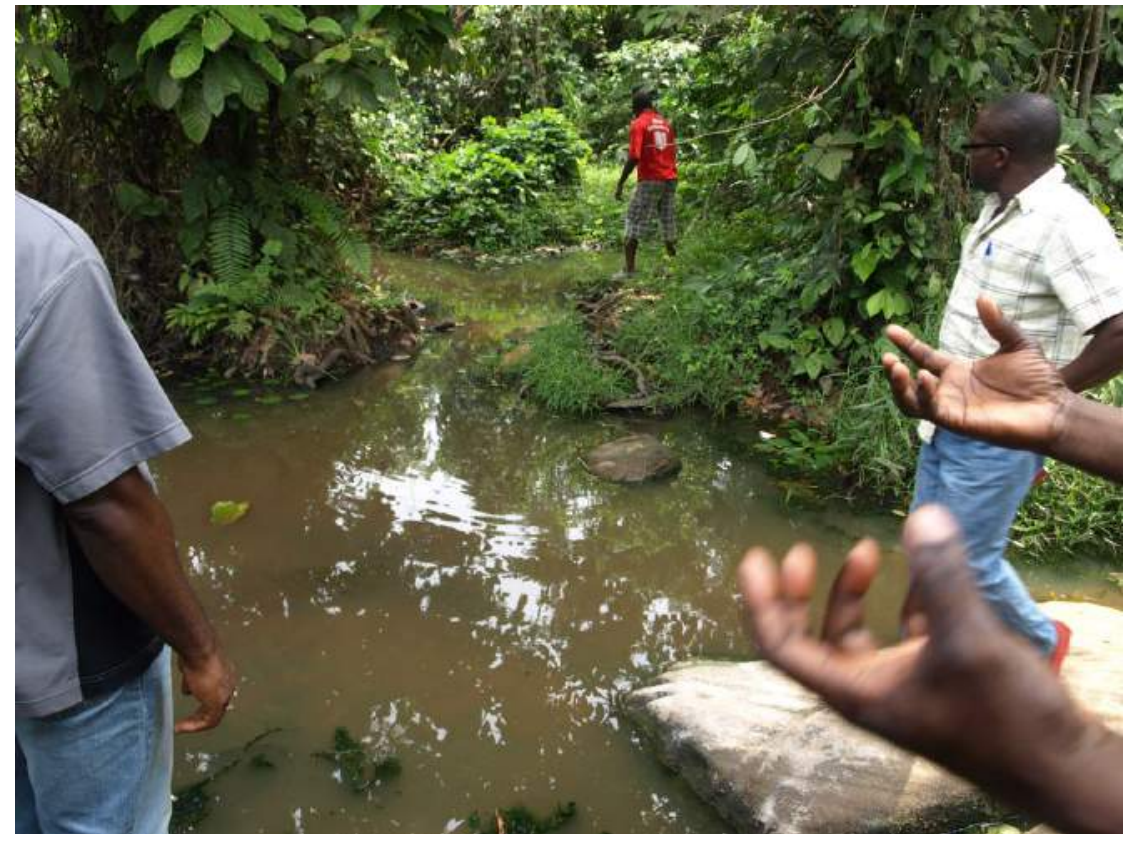

Figure 9. Water source that was once moving is now stagnant after the pipeline's construction, Mpango (Amber Murrey)

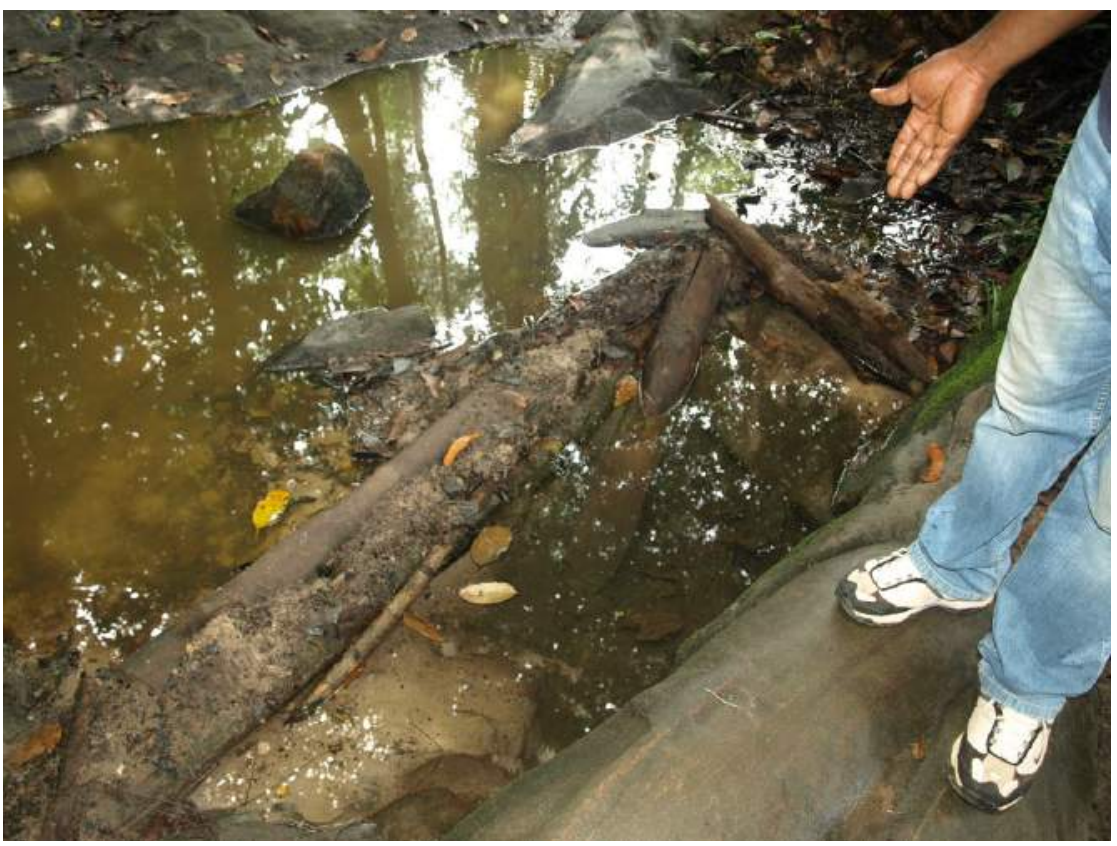

Figure 10. Water sources that were once moving are now stagnant after the pipeline's construction, Bikolo (Amber Murrey)

The first problem is water. It is better to go and see where our people bathe and where we drink [rather than sit here and talk]... Before the pipeline, our water [the small stream near the village] circulated very well. We had no problems with skin infections and other sicknesses, [now] even where we wash our bodies, the water is so dirty.
The woman's words echoed the story told by Simon and Daniel several months before, 450 kilometers away near Nanga. As she spoke, her friends nodded their agreement that "the problem with the pipeline is [first and foremost] the problem of [clean] water."

In a study of the socioeconomic consequences of the pipeline in Cameroon's central province, Bertrand Ndjessa Bessala (2002), notes a marked increase in water- borne illnesses treated in medical centers along the Chad-Cameroon Oil Pipeline corridor, from around 50 in 1998 to over 300 in 2006 and 2007. ExxonMobil whistleblower, Alan M. Dransfield, provides insight into the technical aspects of water pollution and contamination caused by the pipeline. He explained,

\section{The [Chad-Cameroon Oil} Pipeline] has not been designed in accordance with International Standards, i.e. Front End Engineering Design (FEED). ExxonMobil designed the project ad hoc as they went. The [pipeline] crosses between 25/26 major rivers and dozens of smaller streams which are the lifeline to local communities and indigenous people. The correct procedure to install pipeline across such rivers and streams is via pipe jacking/tunneling procedures but ExxonMobil took the cheaper alternative [and conducted] open dig [at] all the river crossings, which allowed the unnecessary poisoning of drinking waters. Moreover, the Hydro testing water equaling millions of gallons of contaminated test water was pumped back into the Ecosystem as opposed to [conducting] the correct disposal of contaminated waste via evaporation pits. The open dig methods also deployed thousands of tons of cement mixed with backfill used as 
erosion control. (Alan M. Dransfield, from an interview with Djamil Ahmat, August 2014)

Inadequate access to safe drinking water in Cameroon is not a reflection of geomorphology, hydrology, or fluvial geomorphology (Mafany et al. 2006). Indeed, Cameroon has the second highest volume of available water in Africa after the Democratic Republic of Congo, with an estimated at 233 billion cubic meters $\left(\mathrm{m}^{3}\right)$. Of this, groundwater constitutes 21.5 percent $\left(57\right.$ billion $\mathrm{m}^{3}$ ) and is used for domestic, industrial, and agricultural activities (Mafany et al. 2006: 47). As aquifers and flowing streams are destroyed and polluted, people are increasingly exposed to waterborne illnesses and "the progressive loss of life." In Mpango, Ndgila André told me,

As soon as they constructed [the replacement wells] they were abandoned - the water is so dirty people only use it to wash clothes... They [COTCO] descend into our villages only when they decide and for reasons they deem necessary. They never respond directly to our complaints. They never respond directly to us at all. Our two streams [from] before the pipeline were very stocked with fish but because they re-routed the streams, the water became stagnant and now it is wetlands... there are no fish and it is swampy habitat for snakes.

There are six water-bottling plants in the country, extracting groundwater predominately in the volcanic region of western Cameroon (Mafany et al. 2006: 47). However, the cost of bottled water is beyond the quotidian purchasing power of most Cameroonians. Inadequate access to safe drinking water is a form of structural violence, as the prioritization of corporate and state profit result in the destruction and pollution of groundwater, with no recourse.

\section{Experiences of structural violence as histori- cally compounded}

In their song, La Fleur (the flower), the Cameroonian musical group, Sumanja, recount,
Ils ont fini par nous sellam

Nos enfants sont tous les buyams

Nos enfants n'ont plus du get-em

Notre espoire c'est Zion

We di cry

Mama cry

In the end, they sold us

Our children are all consumers

Our children have no more money (get-'em)

Our hope is in Zion [slang for marijuana, Zion also references transnational dispossession and resistance by drawing upon Rastafarianism]

We cry

Mama, cry

The parole of the song illustrates some of the grief felt by what people perceive to be the wholesaling of people and resources that describes contemporary Cameroon. In Kribi and Nanga, people told me, "ils nous ont vendu" (they sold us) and "nous sommes toujours les esclaves" (we are still slaves), to explain the "selling out" of national and regional officials to the interests of the pipeline consortium at the expense of people. In this sense, Cameroon has been "bought" and "sold" and children are now bustled into the marketplace, where they are forced to sell everything but have little means (or, little get-em) for survival. This contemporary setting is historically compounded.

"Discovered" by Portuguese explorers in 1472, the social and economic fabric of Cameroon was devastated by the theft of several million people over 430 years, as diverse societies were forcibly incorporated into the transatlantic slave trade by way of the Bight of Biafra. The geography of what is today Cameroon-the country's name is adapted from the 
label given by Portuguese explorers as Rio dos Cameróes, or the river of shrimp in reference to the large prawns of the Wouri estuary-was annexed by Germany in 1884 at the Berlin Conference, a series of meetings between Western European powers to carve up most of the continent for formal colonization in what is known as the "Scramble for Africa."

During the colonial period, from 1884 to 1960 , the diverse peoples and places of Cameroon underwent-often by force-interrelated and simultaneous spatial, religious, linguistic, agricultural, political, and economic transformations. The capture of people for the slave trade was abolished in 1902 although forced labor continued throughout the colonial

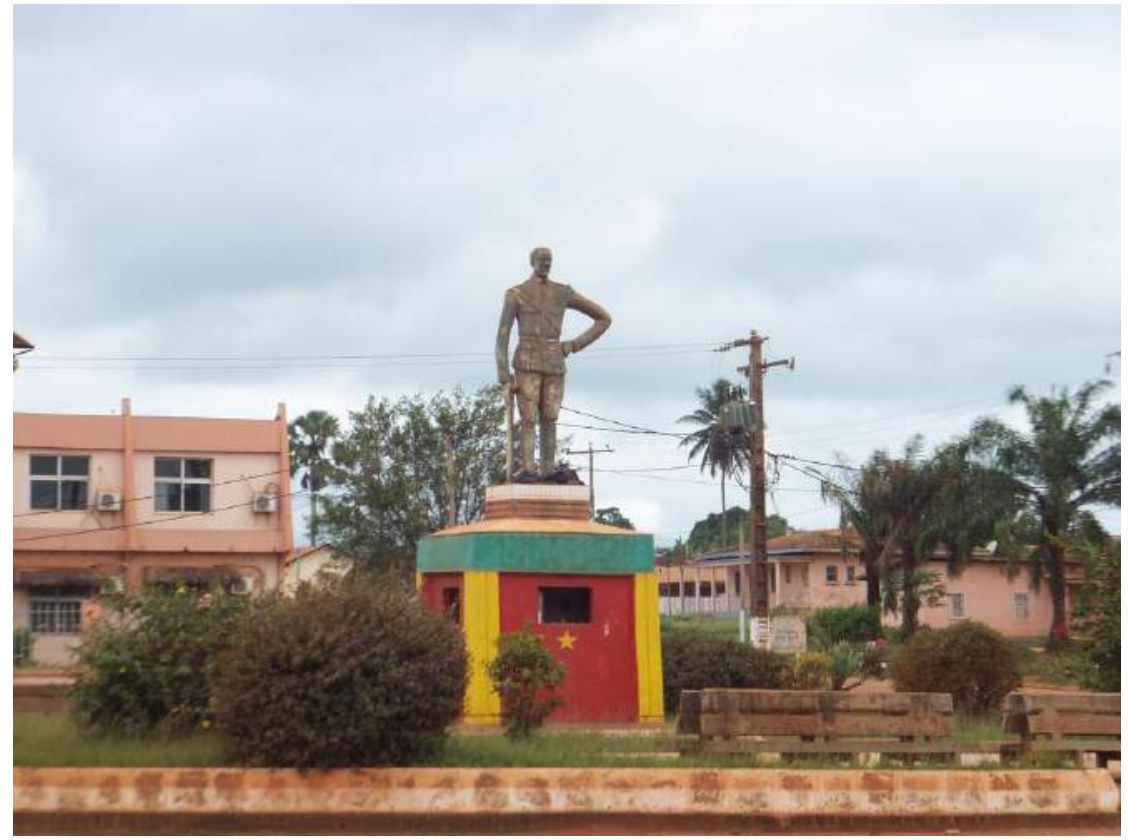

Figure 11. Statue of Chief Nanga Eboko in Nanga town's central Carrefour (Amber Murrey) period under the auspices of corvée, or consigned labor. Colonial domination was enforced "locally" through the implementation of hierarchical chefferies (or chieftancies that subdivided places and people), which facilitated labor exploitation by incentivizing indigenous leaders, handpicked by the colonizers, to provide laborers and to suppress all anticolonial movements (Guyer 1987: 119). This spatial and political partitioning involved the imposition of male chiefs to oversee diverse communities, many of which were previously nonhierarchical and which engaged in systems of gender complementarity (as opposed to European patriarchy); as was the case for the headmen in the communities around what is now Nanga, so named for a pre-colonial political outcast of the area, Nanga Eboko of the Yekaba, who agreed to work with the German lieutenant Dominik to violently suppress the anti-colonial uprisings by the Maka farther east (Owona 1973; Monteillet 2001; Figure 11).

In Kribi, the colonial period was marked with the passage of Portuguese and Dutch slave traders (1470-1880s), German colonizers (1884-1914), and French colonizers (1914-1960) and, like Nanga, the city's name reveals the discursive dominance assumed by European explorers: "Kikiribi" (a fantastical or mystical person) is thought to have been used by the
Portuguese to describe the Baka, Bagyeli, and Bakola forest people of the region's coastal rainforests. In 1914, the Batanga people rose up against German colonizers, who responded by massacring hundreds of people and exiling the remainder of the Batanga to South West Cameroon, several hundred kilometers away, near Mount Cameroon. After the German defeat in WWI, a bloody two-year war was fought among the Germans, British, and French in Cameroon and the German colonizers were forced to retreat to the island of Fernando Pó in 1916. ${ }^{8}$ The Batanga community returned to Kribi in two voyages after Germany's withdrawal and the return is celebrated annually by community-wide celebrations.

Cameroon's formal independence in 1960 was not tantamount to autonomous independence-as was the case for most post-colonial African states (Mamdani 1996) _ in that full political and economic sovereignty was not achieved. Indeed, at independence, the Cameroonian colonial state altered little. Claude Ake (1996: 6) explains that in the African post-colony, "state power remained essentially the same [that is to say] immense, arbitrary, often violent, always threat-

8 Again, the reverberations of colonialism's discursive violence: Fernando Pó was named after the Portuguese explorer, Fernāo do Pó; the island was later renamed Bioko. 
ening." Former colonies continued as the economic "pré carré" (backyard) or the "chasse gardée" (private hunting preserve) of corporate France as Frenchinstalled post-colonial leaders-such as Cameroon's first president, Ahmadou Ahidjo (1924 - 1989), and first prime minister, Paul Biya (1975 - 1982), both selected by departing French colonists - collaborated with French corporations and businessmen-politicians for "the ultimate purpose of exploiting Africans and African wealth" (Le Vine 2004: 4). Cameroon is one of a few countries in the world where the current head of state has a direct lineage to the former colonial powers. ${ }^{9}$ Today, structural violence is engaged on the ground through a popular imaginary rooted in the historical experiences of racism, slavery, and colonization, so that the dispossessions of this pipeline are characterized as "exactement comme" (just like) earlier dispossessions.

This imaginary is founded on shared historic memories of injustice, where these previous experiences provide the foundations for an articulation against the pipeline's particular dispossessions. People spoke about discrete and intersecting forms of violence-including racism ("it's because we're black"), ethnocentrism ("it's because we're Baka"), enslavement ("they treat us like animals"), and colonialism ("we're still not free-who are we to say no?")—unifying past moments with present moments and concurrent projects of dispossession across multiple scales. These characterizations indicate that people have nuanced perceptions of their position within a historical ontological order; specifically the ontological ordering that was the rationalization for slavery and colonialism. Through these narratives, people offer self-aware and historically sensitive orderings of themselves, their neighbors, and their communities at the bottom of what was widely described by people in the villages around Nanga and Kribi as an unfair system.

At the same time, several conversations revealed expectations of future environmental disaster.

9 President Ahidjo was hand-selected at independence as a leader who would be malleable to the interests of the French business class; he selected as his Prime Minister, Paul Biya, who succeeded him upon his withdrawal from power in 1989. Biya remained president at the time this paper was written in 2014 .
Monsieur Tené, whose agricultural field sits atop the pipeline, and whose home is less than one minute's walk from the right-of-way, told me that the pipe "vibrates" and sometimes "makes a loud grumbling noise during the night." So much so that it disrupted their sleep at first. In the beginning, he and his family were frightened and thought something might happen. He sought out COTCO representatives with his worry and was told that the crude must be heated or else it will not flow easily down the pipe. Dissatisfied with the answer, he felt he had little choice and "progressively" they adjusted to the noises, although he spoke of the risk of living along the pipeline. He described the danger of something happening, particularly the pipe burning or bursting (the most commonly heard fear among people in both towns) and his sense that his children would suffer most from such a catastrophe.

Women in the villages around Kribi likewise reported that they joined together to discuss and decided collectively not to risk death, injury, or malchance by planting along the pipeline; instead, they have abandoned their pre-pipeline plots and negotiated land elsewhere, often bearing physical and economic burdens for the choice (including increased walking distance to the plot and the cost of clearing unfarmed forest). In the village of Bisiong, near Kribi, for example, a respected village elder, Mikoum told me, "We women have decided that we no longer grow next to the pipe." Mikoum had closely cropped white hair, her feet were bare and I noticed scarlet red nail polish on her toenails. As we sat outside her home, Mikoum's elder sister laughed occasionally at her bold statements. Mikoum continued,

....and we are afraid that when we burn the fields after harvest that it can create dangerous problems above the pipeline... Women do not even cultivate next to it—we think the fire will spread to the pipe and they will say that the old woman with white hair did it and they will put me in prison!

Mikoum's sister laughed loudly as her sister continued the story, 
We have no [good] memories [of the pipeline]... only this breakable material [she indicated the broken plastic chair upon which I was precariously seated, which had been reattached in several spots by rusting wire]. Ils nous ont escroqué [They scammed us].

Mikoum's sister was entertained by Mikoum's enthusiastic retelling, but despite her humor and narrative talent, people emphasized fear of environmental disaster along the pipeline. Due to the decline in production along the right-of-way and the fear of a pipe explosion, I was only able to locate one woman, Monsieur Tené's wife in Mbong-Sol near Nanga, who continues to plant near the pipeline easement. She continues to farm here because their home is so near the pipeline easement (recall they can hear the oil pumping from their beds at night) that, in the event of a pipeline explosion, the more immediate concern is the location of their home. Monsieur Tené and his family lack the financial means to relocate their family compound (which consists of three separate one-room buildings, an outdoor cooking area, and a roofed stall for sitting outside) farther from the pipeline, despite their consciousness of the risks of life alongside it.

A focus on people's experiences of structural violence illustrates the larger nexus of coloniality (Escobar 2004; Mignolo 2000, 2011) within which the particular violence(s) of the pipeline occur, including how they are compounded and exacerbated over time. These pervasive projects effect dispossessions that harken back to the colonial period, creating elaborate international structures of violence that influence social organization, gender relations, and everyday life. People's accounts reveal that popular imaginations connect contemporary dispossessions of structural violence to earlier forms, as is illustrated in Simon's assertion, "We find ourselves in the olden days, with all the ancient miseries." Contemporary manifestations of structural violence are bound up within neoliberal globalization and its attendant institutions, norms of power, socio-politics, and ideologies, each of which guide labor relations, production, resource distribution, and the processes of accumulation. This perspective highlights the ways in which the violence during the colonial period has been revised-and even augmented - by the violence of the post-colonial present.

\section{Spatially compounded: Mutually constituting and embedded structural violence(s)}

The people I spoke with in Nanga and Kribi struggled to focus exclusively, or even primarily, on the pipeline, as concurrent infrastructural projects impact families and communities. In Kribi, for example, a group of people urged me to research the Kribi Deep Sea Port Project, which, they explained as they drew connections between the port and the pipeline, also failed to provide long-term or skilled employment for local people. In Nanga, people told me about instances of foreigners trekking through hard-to-access rainforests with "strange machines," reappearing days later to offer exchanges of dried fish and rice for the land's timber; they speculated that the coveted resource lay under the timber. Two men criticized the industrial sugarcane plantations of SOSUCAM (Societe Sucriere $d u$ Cameroun, a subsidiary of the French food giant, SOMDIAA) for pumping waste and pesticides into streams near Nkoteng. They urged me to document the pollution of surface water. A Nanga woman, whose crops were destroyed by the pipeline, later had portions of her land appropriated for the construction of the Yaoundé-Bertoua Autoroute, contracted to the China Water and Electricity Corporation (CWE). During our conversation, she showed me her preciously guarded official documents from both projects.

Elie, in Mpango near Kribi, said, "Today it is not a problem of COTCO or the pipeline. The problem is bigger than COTCO and we must speak between ourselves as villagers to find solutions because we will find none at their door." These narratives indicate that the pipeline is one violent project within a complicated matrix of structurally violent capitalist projects that affect everyday life in and around Nanga and Kribi as a multitude of corporate and political interests convene and intervene in "local" spaces, centering on the economic impetus for raw materials. One consequence of the convergence of multiple deforestation and landscape transforming infrastructural projects is a change in weather patterns, particularly in the last decade. Coastal erosion, pesticide pollution, indus- 
trial waste oil spills, deforestation, and desertification threaten Cameroon's mega-biodiversity and contribute to the unpredictable weather patterns identified by Maman Medgongo.

Like several of her neighbors, Maman Medgongo attributed the unusual climate patterns over the past ten years to the presence of the oil pipeline and the deforestation that accompanied it. She characterized farming as "playing chess" with the rain and the sun: "I mostly lose," she said. People in both Nanga and Kribi emphasized the disruption of the seasonal calendar by climate change. Cameroon's rainy season, which usually starts in June, arrives earlier and earlier, sometimes as early as February. The deforestation brought about by the pipeline occurred within a larger context of deforestation in Cameroon. This was made apparent during my conversation with Jacques, the chief of Nginda (near Nanga).

He was burning big brush piles when I arrived, adeptly positioning his cigarette at the corner of his mouth while he spoke and shook my hand simultaneously. He asked if I knew where the pipeline passed nearby and I admitted to him that I couldn't see it although I knew I had to be standing practically on top of it. Jacques explained that the brush and vegetation is cut periodically along the pipeline right-of-way, approximately every three months (although there is never any indication when it will happen). During my time in Nanga, it had been over six months since the foliage had been cleared and, as a result, it was difficult to ascertain the pipe's exact location. For the people who lived along it, of course, there was no difficulty.

"We don't know why they've let it go so long," Jacques told me as we walked from his home to the road to where he could show me the pipe. Jacques was an energetic and lithe man in his late forties. On that day he was wearing jeans, a T-shirt and white tennis shoes. As we walked up the road in front of his house, I had to almost jog to keep up with him. He spoke quickly and confidently without prompts, recalling exact dates, places, and names. He stopped me near a section of the road, indicating a moist section of ground where the pipeline passed underfoot. As we spoke, a logging straight truck barreled down on us and we raced to the side of the road. Trucks carrying the massive logs of old-growth rain forest pass through Nanga every day, en route to the industrial sawmills of Douala, where the logs are prepared for export. Chief Jacques scoffs at "les gens dans le bois" (the people "in" wood), calling them the "Mafia" of Cameroon. In a systematic exploitation of wood in the eastern part of Cameroon, the chief says, "everyone is complicit." Rosa, likewise, late told me a story of a man who came to their familial plot to cut down some wood; meanwhile, he stole several bushels of plantains, which he hid in his truck. I heard many similar stories.

The leaves of the trees along the roadside were red-tinted, covered with dust from the nearly constant truck traffic, transporting this raw lumbermahogany, ebony, and teak-from the dense equatorial rainforest of the Congo Basin to Douala's port. With 24 million hectares of rainforest, Cameroon is the fourth most ecologically diverse African country. Cameroon's National Biodiversity Strategy and Action Plan (NBSAP) identifies 805 fish species, 8,000 tree species, 409 mammal species, 183 reptile species, and 849 bird species. The exploitation of this biodiversity fits into the long history of structural violence in Cameroon, a history which people on the ground are acutely aware of. Commercial logging began during the colonial period in the 1880s and expanded in the 1920s (Topa et al. 2009: 13). Cameroon remains one of Africa's largest producers of timber and from the 1980s to mid-1990s; it was the world's fourth largest timber exporting country (Ichikawa 2006; Ngalame 2013). Since the 1980s, timber has accounted for approximately 25 percent of Cameroon's foreign exchange, second only to petroleum and far exceeding any other agricultural commodity (Topa et al. 2009: 13).

Cameroon's forests are disappearing at an annual rate of close to one percent. Between 1990 and 2010, 4.5 million hectares (approximately 45,000 square kilometers) of forest cover was destroyed (UN Food and Agriculture Organisation). In 1994, the government introduced a number of forest policy reforms, placing 30 percent of the surface area under production. However, Global Witness recently released a report exposing a system of "shadow 
permits," highlighting the allocation permits for small business and artisans to industrial logging companies (Mwanamilongo 2013). Greenpeace International has likewise documented instances in which illegal timber was labeled as legal and exported with false documentation, including a report of illegal logging near the site of the Memvé élé Dam project, construction for which is contracted to the Chinese company, Sinohydro. Greenpeace recently reported on illegal logging by Uniprovince-a subsidiary of SGSO Cameroon Holding Ltd., which is registered in the Cayman Islands-where 2,500 hectares of land were razed, to make way for the American-owned Herakles Farm palm oil plantation. The report, titled "License to Launder," indicates that Cameroon's Minister of Forests was aware of the allocation of the unlawful logging permit that allowed the clear-cutting to occur (Greenpeace International 2014).

The convoluted power nexus that creates the groundwork for structural violence in Cameroon is tangible in such moments. Deforestation, oil spills, soil erosion, and groundwater contamination are forms of structural violence affected by the pipeline. If we evaluate each of these violence(s) in turn or in isolation, we lose sight of their overlapping and intersecting configurations in lifescapes and landscapes; we also perform a decontexualization that is complicit with the perpetuation of structural violence.

\section{Final thoughts}

What Chief Ngali described as the progressive loss of life fits into the body of critical scholarship on how particular populations are made "redundant," "superfluous," or "disposable" by the patterns of uneven development entrenched in the practices of modernity (Agamben 1998; Mbembe 2003; Bauman 2013). Some of these theoretical projects implicitly overlook the role of human agency. Even as patterns of global political economic exchange force people to the margins, peripheries, and dead-lands, people struggle, laugh, mourn, feel, resist, acquiesce, and act in complex ways. Moreover, there is often-as reflected in Ngali's commentary on the "enforced waiting for death" - an astute consciousness of self, place, and community within this nexus of structural violence, defying any easy characterization of people as "disposable." In Kribi, a group of men explained the risks of living alongside the oil pipeline in transnational ways. They referenced the 2010 Deepwater Horizon oil spill in the Gulf of Mexico and ecological destruction in the oil exploitation of Ogoniland in the Niger Delta. Describing groups of people as "superfluous," "wasted," and/or "redundant"—even in a deeply critical analysis of the processes that convene to make this so-risks solidifying and finalizing abandonment/disposability as such. Turning to a framework of structural violence that centers on people's narratives, opens up other possibilities - most particularly an engagement with agency and people's understandings of their placement in a longue durée of structural violence.

A body of scholarship on structural violence posits it as invisible and, therefore, any project to combat it begins with the unveiling of such violence. This begs the question: Structural violence is invisible to whom? For the people who live amidst structurally violent forces, this violence is hyper-visible, despite discursive attempts to cloak, bury, and efface by those in power. Dignity, shame, pain, and pride inform resistance and response to structural violence as much as - or more than-the visibility or invisibility of "the perpetrators." In a context of increasingly porous power structures and as violence is embedded within racialized hierarchies, multilayered, and multispacialized global transactions, the actors and actions of structural violence do not need to be made "visible" to those who live within structurally violent nexuses. Recognizing this fundamentally alters the scholaractivist project of defining and working against forces of structural violence.

The search for greater visibility and even greater visibility-including those of transparency initiatives, full disclosure, and liberal principals that are now embedded within a transnational corporate responsibility discourse-is a cognitive snare, restricting the realm of possible solutions to corporate volunteerism and excluding narratives of loss outside a quantifiable, calculable ordering of the world according to the dogma of scientism (recall, for example, Pierre's nuanced awareness of the flaws of "proof," which 
limit the power of his testimony without a scientific examination of changes in soil temperature along the pipeline route). To "see" something is to encounter it in a particular field of visibility, but fields of vision are created through political, cultural, and scientific processes and these processes determine what subjects and objects are understandable, important, and valid-and therefore visible. Euro-American audiences are spatially disciplined to not "see" the suffering caused by the particular spatial privileges of living in Euro-American regions (what can be described as willful blindness). This spatial conditioning is fundamental to the perpetuation of a globalized financial-political-policy regime (Peet 2003: 14-23) that perpetuates historically rooted, spatial practices of structural violence.

Cultivating spaces of peace-not just the absence of direct war as in the dominant Western liberal concept of peace, but a nonviolent peace founded upon local notions and practices of wellbeing (Daley 2014: 66-7)—entails long-term collaborative work to dismantle structures of exclusion by doing intellectual and creative work that emphasizes the vocabularies and languages that dispossessed people use to stake claims in structurally violent contexts. The theory of structural violence has its origins in peace studies and as such there is an active component imbedded within the theoretical work on structural violence: it is an incitement against the complex sociopolitical processes and colonial discourses that produce historically rooted, spatially compounded, and acutely visible violence of displacement in-place experienced through hunger, thirst, and the "death of the earth" (Lefebvre 1976; Blaikie 1985). By asserting and foregrounding the violence(s) of these processes, we demystify the colonial monopoly on the discourse of violence, which would cast entire populations as either perpetual threats to or superfluous in the colonial global order. Work on structural violence has almost unanimously involved the foregrounding of the need to build resolve against and work towards the unbinding of ourselves from such systems. An immediate step in this direction would entail the decommissioning of the ChadCameroon Oil Pipeline alongside a sustained debt relief program, which would, critically, open up space for an unprecedented level of self-determination, as opposed to the current system where regulations and policies are determined by external bodies through debt restructuring schemes.

Acknowledgments: This research was funded through a Clarendon Fellowship at the University of Oxford. Travel to Cameroon was partially supported by the Bowers Fund Award, the Ann Ward Fund, and the Charles Green Award through Jesus College, Oxford. I had fruitful and insightful conversations with colleagues on my approach to structural violence, including Dali Islam, Patricia Daley, and members of the Transformations Cluster at SoGE, Oxford. Audience members at the 8th Annual Interdisciplinary Conference at the Centre of Applied Philosophy Politics and Ethics (CAPPE) at the University of Brighton, UK provided critical feedback on an earlier draft of this paper.

\section{References}

Agamben, Giorgio. 1998. Homo Sacer: sovereign power and bare life. Stanford, CA: Stanford University Press.

Ahmat, Djamil. 2014. Interview with Alan M. Dransfield. Al Wihada. Available at: http://www.alwihdainfo.com/Chad-Cameroon-Pipeline-operating-in-aLegal-Void_a12429.html (accessed 15 Oct. 2014)

Ake, Claude. 1996. Development and democracy in Africa. Washington, DC: Brookings Institution Press.

Amnesty International. 2009. Cameroon: Impunity underpins persistent abuse. London: Amnesty International Publications. Available at: http://www.univie.ac.at/bimtor/dateien/cameroon_ ai_2009_persistent_abuse.pdf (accessed 13 Oct. 2014)

Arguedas, J. M. 1985. Yawar fiesta. Barraclough, F. H. (trans.). Austin: University of Texas Press.

Bauman, Zygmunt. 2013. Wasted lives: modernity and its outcasts. Cambridge and Oxford: Polity.

Bruner, J.S. 1990. Acts of meaning. Cambridge: Harvard University Press. 
Castree, Noel and Paul Chatterton, Nik Heynen, Wendy Larner and Melissa W. Wright (eds.). 2010. The point is to change it: geographies of hope and survival in an age of crisis. Malden, MA: Blackwell Publishers.

Castro-Gómez, Santiago. 2007. The missing chapter of empire: Postmodern reorganization of coloniality and post-fordist capitalism. Cultural Studies 21(2-3), 428-448.

Cesera, M. 1982. Reflections of a woman anthropologist: No hiding place. New York: Academic Press.

Daley, Patricia. 2014. Unearthing the local: hegemony and peace discourses in Central Africa. In McConnell, Fiona, Megoran, Nick and Williams, Philippa (eds) Geographies of peace, 66-86. London and New York: I.B. Tauris.

DeLancey, Mark Dike, Rebecca Neh Mbuh and Mark W. DeLancey. 2010. Historical Dictionary of the Republic of Cameroon. Plymouth, UK: Scarecrow Press, Inc.

ECAM 3. 2007. Cameroon's third household survey, National Institute of Statistics.

Endeley, Joyce and Sikod, Fondo. 2007. The social impact of the Chad-Cameroon oil pipeline: How industrial development affects gender relations, land tenure, and local culture. Lewiston, New York: The Edwin Mellen Press.

Endeley, Joyce B. M. 2010. The politics of gender, land and compensation in communities traversed by the Chad-Cameroon Oil Pipeline Project in Cameroon. Tsikata D, Golah P (eds) Land tenure, gender and globalisation: Research and analysis from Africa, Asia and Latin America, 145-179. New Delhi: Zubaan.

Escobar, Arturo. 2004. Beyond the third world: Imperial globality, global coloniality, and anti-globalisation social movements. Third World Quarterly 25 (1), 207-230.

Esso Chad/Cameroon (1997) Supporting Documents - Volume 3. Available at: http://www.
essochad.com/Chad-English/PA/Newsroom/TD_ Documentation_Supporting_3.aspx (accessed 13 Oct. 2014)

Farmer, Paul. 2004a. On suffering and structural violence: A view from below. In Scheper-Hughes N, Bourgois PI (eds) Violence in war and peace: An anthology, 281-289. Malden, MA: Blackwell Publishing Ltd.

Farmer, Paul. 2004b. An Anthropology of structural violence. Current Anthropology 45(3), 305-325.

Galtung, Johan. 1969. Violence, peace and peace research. Journal of Peace Research 6(3).

Giddens, Anthony. 1984. The constitution of society: Outline of the theory of structuration. Cambridge: Polity Press.

Gramsci, Anthony. 1971. Selections from the prison notebooks of Anthony Gramsci.

Hoare, Quentin and Geoffrey Nowell Smith (trans). New York: International Publishers.

Grovogui, Siba N. and Leonard, Lori. 2007. Oiling tyranny? Neoliberalism and global governance in Chad. Studies in Political Economy 79, 35-59.

Greenpeace International. 2014. License to launder: How Herakles Farms' illegal timber trade threatens Cameroon's forests and VPA. JN 467, Amsterdam: The Netherlands. Available at: http:// www.greenpeace.org/international/Global/international/publications/forests/2014/Licence-to-Launder. pdf (accessed 15 Oct. 2014)

Gupta, Akhil. 2012. Red tape: bureaucracy, structural violence, and poverty in India. Durham, NC: Duke University Press.

Guyer, Jane I. 1987. Feeding Yaoundé, capital of Cameroon. In Guyer, Jane I. (ed), Feeding African cities, 112-153. Manchester, UK: Manchester University Press. 
Harvey, David. 1996. Justice, nature and the geography of difference. Malden, MA and Oxford, UK: Blackwell Publishers.

Ichikawa, M. 2006. Problems in the conservation of rainforest in Cameroon. African Study Monographs 33, 3-20. Kyoto: Kyoto University Press.

Keenan, Jeremy. 2005. Chad-Cameroon Oil Pipeline: World Bank and ExxonMobil in 'last chance saloon.' Review of African Political Economy 104(5), 395-477.

Lefebvre, Henri. 1976. L'état dans le monde moderne. Vol. 1 of De l'état. Paris: UGE.

Le Vine, Victor. 2004. Politics in francophone Africa. Bolder, CO: Lynne Rienner Publishers.

Magaramombe, Godfrey. 2008. Agrarian displacements, replacements and resettlement. 'Displaced in place': Farm workers in Mazowe District. Paper presented at conference on 'Political economies of displacement in post-2000 Zimbabwe,' Nordic Africa Institute and Forced Migration Studies Programme, University of the Witwatersrand.

Mafany, GT, Fantong WY, and Nkeng G.E. 2006. Groundwater quality in Cameroon and its vulnerability to pollution. Yongxin X, Usher B (eds), 47-55. Groundwater pollution in Africa. London, Leiden, New York, Philadelphia, Singapore: Taylor and Francis.

Magaramombe, Godfrey. 2010. 'Displaced in place': Agrarian displacements, replacements and resettlement among farm workers in Mazowe District. Journal of Southern African Studies 36(2), 361-375.

Mamdani, Mahmood. 1996. Citizen and subject: Contemporary Africa and the legacy of late colonialism. Princeton, NJ: Princeton University Press.

Mbembe, A. 2003. Necropolitics. Meintjes, L. (trans) Public Culture 15(1), 11-40.
Mignolo, Walter. 2000. Local histories/global designs: Coloniality, subaltern knowledges and border thinking. Princeton: Princeton University Press.

Mignolo, Walter. 2011. The darker side of Western modernity: Global futures, decolonial options. Durham and London: Duke University Press.

Mollett, Sharlene. 2014. A lost paradise: Garifuna land, labour, and displacement-in-place. Latin American Perspectives 20(30), 1-19.

Monteillet, Nicolas. 2001. Tradition orale, utilisation des généalogies et nouvelles entités politiques, Nanga Eboko, Cameroun. Journal des Africanistes 71(2), 95-112.

Murrey, Amber. Forthcoming 2015. Lifescapes of a pipedream: a decolonial mixed-tape of structural violence and resistance along the Chad-Cameroon Oil Pipeline. PhD dissertation, School of Geography and the Environment, University of Oxford, Oxford, UK.

Mwanamilongo, Saleh. 2013. Logging permits are being abused in Africa. Associated Press. http:// www.omaha.com/news/logging-permits-are-beingabused-in-africa/article_9ba614d1-2e46-56be-abe40519f5ef58a0.html?TNNoMobile (accessed 19 Jun 2014)

Ndjessa Bessala, Bertrand J. 2002. Impacts socioeconomiques du projet de pipeline Tchad-Cameroun le long du corridor dans la province du centre (Cameroun). $\mathrm{PhD}$ dissertation, Economie et finance, Université de Dschang, Ingénieur agro-socio-economiste. http:// www.memoireonline.com/12/09/2991/m_Impactssocioeconomiques-du-projet-de-pipeline-TchadCameroun-le-long-du-corridor-dans-la-province-d0. html (accessed 4 Apr 2014).

Ngalame Elias. 2013. Cameroon hopes EU timber labelling can protect forests. Thomas Reuters Foundation. http://www.trust.org/item/201305141251071spkt/ (accessed 14 May 2013) 
Nixon, Robert. 2011. Slow violence and the environmentalism of the poor. Cambridge, Massachusetts and London: Harvard University Press.

Owona, Adalbert. 1973. La naissance du Cameroun (1884-1914). Cahiers d'études africaines 13(49), 16-36.

Pankhurst, Alula and Piguet, Francois. 2009. Moving people in Ethiopia: Development, displacement, and the state. Oxford: James Currey.

Peet, Richard. 2003. Unholy trinity: The IMF, World Bank and WTO. London and NY: Zed Books Ltd.

Polkinghorne, D. 1988. Narrative knowing and human sciences. Albany: SUNY Press.

Quinn, Frederick. 2006. In search of salt: Changes in Beti (Cameroon) society, 1880-1960. New York and Oxford: Berghahn Books.

Raghuram, P. and Madge, C. 2006. Towards a method for postcolonial development geography: possibilities and challenges. Singapore Journal of Tropical Geography 27(3), 270- 288.

Reck, Gregory G. 1993. Narrative and social science: Reclaiming the existential. Issues in Integrative Studies 11, 63-74.

Schwartz, Brendan and Valery Nodem. 2009. Humanitarian disaster in the making along the ChadCameroon Oil Pipeline-who's watching? AlterNet.
Available at: http://www.alternet.org/story/144303/a humanitarian_disaster_in_the_making_along_the_ chad-cameroon_oil_pipeline_--_who's_watching (accessed 13 Oct. 2014)

Silverstein, Ken. 18 June 2003. AIDS could follow African pipeline. Los Angeles Times, A1-A12.

Sumanja, featuring Miguel. 2012. "La fleur." Music video available at: http://www.youtube.com/ watch?v=Y70lddTa6bw (accessed 15 Oct. 2014)

Topa, Giuseppe and Karsenty, Alain, Megevand, Carole, and Debroux, Laurent. 2009. The rainforests of Cameroon: Experience and evidence from a decade of reform. Washington, D.C.: The International Bank for Reconstruction and Development/The World Bank.

UNICEF. 2013. Country Statistics-Cameroon. Available at: http://www.unicef.org/infobycountry/ cameroon_statistics.html (accessed 15 Oct. 2014)

Wacquant, Loïc. 2004. Response to Paul Farmer, "An anthropology of structural violence." Current Anthropology 45(3), 322.

World Food Programme. 2012. Country Programme Cameroon $200330 \quad$ (2013-2017). Executive Board, Second Regular Session. Available at: http://one.wfp.org/operations/current_operations/ project_docs/200330.pdf (accessed 13 Oct. 2014)

\section{(All figures have been produced by the author.)}

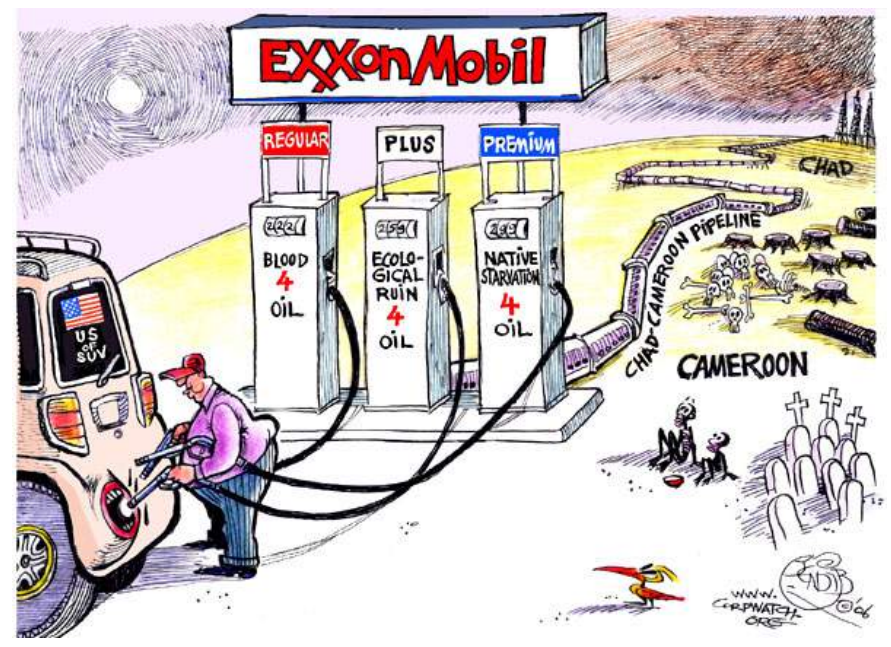

